\title{
IMÁGENES PARA LA PREDICACIÓN DEL EVANGELIO. PRESENCIA DE LAS IMPRESE SACRE DEL OBISPO ARESI EN LA ORATORIA SAGRADA ESPAÑOLA DE LA EDAD MODERNA
}

\author{
POR \\ JosÉ JAVIER AZANZA LÓPEZ \\ Universidad de Navarra \\ jazanza@unav.es
}

\section{RESUMEN}

En el primer tercio del siglo XVII, el teatino Paolo Aresi, obispo de Tortona, escribe las Imprese sacre, colección de imágenes simbólicas para uso de predicadores que responde a la preocupación por utilizar en el discurso religioso los instrumentos de persuasión más eficaces. En España, su conocimiento fue temprano, y su aplicación homilética resultó extendida, tanto en el tiempo como en el espacio. Al alcanzar el IV Centenario de su publicación, el objetivo de este trabajo es analizar el uso de las Imprese sacre en la oratoria sagrada española, en concreto en su explicación de los pasajes del Evangelio.

PALABRAS CLAVE: Paolo Aresi; España e Italia; siglos XVII y XVIII; literatura emblemática; oratoria sagrada.

\section{IMAGES FOR PREACHING THE GOSPEL. THE PRESENCE OF THE IMPRESE SACRE OF BISHOP ARESI IN THE SPANISH SACRED ORATORY OF THE MODERN AGE}

\begin{abstract}
In the first part of the Seventeenth Century, the Theatine Paolo Aresi, Bishop of Tortona, wrote the Imprese sacre, a collection of symbolic images for the use of preachers which can be seen as a response to the concern to use the most effective means of persuasion in discourses such as the homily. In Spain, the Imprese sacre was well known early on, and its application in homilies was widespread, in both time and space. When reaching the IV Centennial of its publication, the aim of this paper is to analyse the use of the concepts from Aresi's work in Spanish Sacred Oratory, specifically in its explanation of the passages of the Gospel.
\end{abstract}

KEY WORDS: Paolo Aresi; Spain and Italy; 17th and 18th centuries; emblematic literature; sacred oratory.

$\begin{array}{ll}\text { Recibido/Received } & 17-05-2012 \\ \text { Aceptado/Accepted } & \text { 06-04-2015 }\end{array}$

«En el Padre Don Pablo Aresio, después Obispo de Tortona, admiran los Doctos lo peregrino, lo profundo, y lo universal en Divinas, y Humanas Letras». ${ }^{1}$

LOS LIBROS DE EMBLEMAS COMO RECURSO DE LA ORATORIA SAGRADA ESPAÑOLA

Resulta innegable el hecho de que, a la hora de componer su homilía, los oradores de la Edad Moderna acudían a fuentes de muy variada naturaleza, evidenciando así su vasta cultura literaria. Dentro de este auténtico arsenal

Oliden, G. 1732. Diálogos del purgatorio, para examen de un libro: 44. Alcalá y Madrid en la Librería de Juan de Buytrago. de erudición, ocupaban un lugar preferente las Sagradas Escrituras, así como los Padres de la Iglesia y los escolásticos medievales de mayor relieve; también los poetas, filósofos e historiadores grecolatinos formaban parte del repertorio de obras citadas, al igual que autores más cercanos a la época; y no faltaban tampoco referencias procedentes de los libros de emblemas: no en vano, la enseñanza didáctico-moral que podía extraerse de las composiciones emblemáticas hacía de estas un elemento sumamente apropiado para insertarlas en el discurso religioso, al que proporcionaban además un sello de distinción intelectual por su naturaleza culta y erudita. Nos situamos así en el contexto de las imágenes para la predicación, que vino acompañado de una abundantísima producción de textos devocionales ilustrados. 
El uso del emblema, de la empresa o del jeroglífico, fue práctica común entre los oradores, e incluso algunas instrucciones de predicadores lo aconsejaban por su carácter didáctico y por la enseñanza moral que generalmente incorporaban, siempre y cuando se hiciese con moderación y los ejemplos se extrajesen de autoridades en la materia. ${ }^{2}$ Numerosas contribuciones han puesto de manifiesto la relevancia de emblemas y jeroglíficos como adorno de la oratoria sagrada, destacando las de Aurora Egido ${ }^{3}$ y Giusseppina Ledda, ${ }^{4}$ a partir de las cuales otros especialistas han abordado el tema. ${ }^{5}$ Como significa Sagrario López Poza, "los muchos sermones de los siglos XVI-XVIII que han hecho que el eco del púlpito nos llegue hasta nuestros días, nos permiten comprobar hasta qué punto las alusiones a emblemas y jeroglíficos eran transmitidas por los predicadores, que actuaban como intermediarios culturales». ${ }^{6}$

2 Así lo significaba en 1617 el predicador real Francisco Terrones en su Instrucción de Predicadores, con una mención explícita a Alciato y Pierio Valeriano. Terrones del Caño, F. 2001. Obras Completas: 210211. Valladolid: Junta de Castilla y León. Universidad de León.

3 Egido Martínez, A. 1992. «Emblemática y literatura», en A. Egido (coord.), Historia y crítica de la literatura española, Vol. 3, Tomo 2. Siglo de Oro: Barroco: primer Suplemento: 81-85. Barcelona: Editorial Crítica. Sostiene A. Egido que "dejando a un lado los certámenes y academias, la sermonística ocupa un lugar relevante, junto con la literatura religiosa en general, siendo estas las ramas que destacan como más florecientes en el uso y abuso del emblema y hasta en lo que podríamos llamar emblematización de la cultura».

Véanse sus aportaciones a este tema en: Ledda, G. 1989. «Predicar a los ojos». Edad de Oro 8: 129-142; Ledda, G. 1996. "Los jeroglíficos en los sermones barrocos. Desde la palabra a la imagen, desde la imagen a la palabra», en S. López Poza (ed.), Literatura emblemática hispánica: actas del I Simposio Internacional: 111-118. La Coruña: Universidade da Coruña; Ledda, G. 1998. «Emblemas y configuraciones emblemáticas en la literatura religiosa y moral de siglo XVII», en M. C. García de Enterría y A. Cordón Mesa (eds.), Actas del IV Congreso Internacional de la Asociación Internacional Siglo de Oro, Vol. 1: 45-74. Alcalá de Henares: Universidad de Alcalá; y Ledda, G. 2003. La parola e l' immagine. Strategie della persuasione religiosa nella Spagna secentesca. Pisa: Edizioni ETS.

Es el caso -entre otros- de Cerdán, F. 1993. "La emergencia del estilo culto en la oratoria sagrada del siglo XVII». Criticón 58: 6172; Pérez Martínez, H. 2000. «El emblematismo argumentativo en un sermón novohispano. El panegírico de Palavicino sobre La fineza mayor», en V. Mínguez (ed.), Del Libro de Emblemas a la Ciudad Simbólica, Vol. II: 603-620. Castellón: Universitat Jaume I; Tanganelli, P. 2002. «Descripción jeroglífica y retórica de la empresa: Pedro de Valderrama y Sambuco», en A. Bernat y J. T. Cull (eds.), Los días del Alción. Emblemas, Literatura y Arte del Siglo de Oro: 533-545. Barcelona: J. J. de Olañeta; Cull, J. T. 2004. "The Baroque at Play: Homiletic and Pedagogical Emblems in Francisco Garau and other Spanish Golden Age Preachers», en F. A. de Armas (ed.), Writing for the Eyes in the Spanish Golden Age: 237-256. Lewisburg: Bucknell University Press; Bernat Vistarini, A. y Cull, J. T. 2010. "Pues si miramos en este escudo imperial: imbricación de palabra e imagen en el sermón de Jerónimo de Florencia (S. J.) para las exequias funerales en honor de la emperatriz María de Austria», en I. Arellano y A. Martínez Pereira (eds.), Emblemática y religión en la Península Ibérica (Siglo de Oro): 101-127. Madrid \& Frankfurt: Iberoamericana \& Vervuert; y Azanza López, J. J. 2010. «Alciato moralizado. Los emblemas alciatinos como exempla en la oratoria sagrada», en Emblemática y religión en la Península Ibérica (Siglo de Oro): 71-100. Madrid \& Frankfurt: Iberoamericana \& Vervuert.

6 López Poza, S. 2000. «Los libros de emblemas como tesoros de erudición auxiliares de la inventio», en R. Zafra y J. J. Azanza (eds.), Emblemata Aurea. La Emblemática en el Arte y la Literatura del Siglo de Oro: 277. Madrid: Akal. Afirma López Poza que algunos libros de emblemas dejan ver con facilidad que sus autores tuvieron en mente
En nuestro caso, la consulta y análisis de más de cuatro mil sermones publicados en España entre 1604 y 1795, nos permite llegar a algunas conclusiones válidas en la relación existente entre literatura emblemática y oratoria sagrada en la Edad Moderna. Como cabía esperar, las obras más utilizadas son los Hieroglyphica de Pierio Valeriano, publicados en $1556,{ }^{7}$ y el Mondo simbolico del agustino Filippo Picinelli, cuya primera edición en lengua toscana apareció en Milán en 1653, traducido con posterioridad al latín por Agustín Erath. ${ }^{8}$ Se trata en ambos casos de repertorios especialmente creados como "tesoros» auxiliares de la inventio oratoria, por cuanto quienes deseaban enriquecer su homilía hallaban en ellos abundantes fuentes de erudición dispuestas y engarzadas con elegancia y sabiduría. ${ }^{9}$ Su importancia radica no solo en el hecho de que constituyen por sí mismos un inagotable catálogo de información al servicio de la elocuencia para atraer por medio de la palabra -ya sea oral o escrita-, sino en que recogen ejemplos de otros libros de emblemas de los que se servían los oradores sin necesidad de acudir a los textos originales, circunstancia que facilitaba su labor.

A los anteriores siguen otras dos obras también concebidas como repertorios específicos de jeroglíficos y símbolos destinados al estímulo de la imagen visual: los Commentaria Symbolica de Antonio Ricciardo, más conocido como Brixiano, publicados en 1591, y el Electorum symbolorum et parabolarum historicarum syntagmata, del jesuita Nicolao Caussino, que salió de las prensas parisinas de Romanus de Beauvais en 1618 y cuyos dos primeros libros -de un total de doce- fueron traducidos a la lengua castellana por Francisco de la Torre en 1677.

Numerosas son igualmente las citas al Emblematum liber de Alciato, una de las fuentes más consultadas en la oratoria sagrada española, por ser autoridad reconocida en la materia e incluso admitida en las instrucciones de predicadores. ${ }^{10}$ Ya en un nivel intermedio se sitúan un sinfín de repertorios emblemáticos, cuya autoría corresponde a autores de diverso origen y procedencia; ${ }^{11}$ y entre ellos figuran

a la hora de crearlos que el público principal que iba a consultarlos eran los predicadores, destinatarios en gran medida de la erudición que almacenaban.

Valeriano, P. 1556. Hieroglyphica, siue de sacris Aegyptiorum literis commentarii. Basileae: Michael Isengrin. Valeriano publicó por primera vez su obra en latín en 1556, en Florencia, de forma incompleta, y ese mismo año, completa en la imprenta de Insegrin en Basilea; después se tradujo al francés y al italiano.

8 Piccinelli, F. 1653. Mondo simbolico o sia Università d'imprese suelte, spiegate, ed illustrate con sentenze, ed eruditioni sacre, et profane. In Milano: Per lo Stampatore Archiepiscopale. De su amplia difusión e influencia da buena prueba el gran número de ediciones tanto en el idioma original toscano como en su traducción latina llevada a cabo en 1680-81 por el agustino alemán Agustín Erath, que amplió el repertorio añadiendo muchas fuentes, sobre todo de autores germanos.

9 López Poza, S. 2000: 263-279.

10 Azanza López, J. J. 2010: 71-100.

11 Signifiquemos los nombres de Vincenzo Cartari, Giovanni Ferro, Achille Bocchi, Camillo Camilli, Scipione Bargagli, Scipione Ammirato, Giulio Cesare Capaccio, Joachim Camerarius, Otto Vaenius, Herman Hugo, Antonius Ghinter, Henricus Engelgrave, Julius Zincgreff, Georgette de Montenay, Joannes Sambucus, y los españoles Juan de Borja, Juan de Horozco y Covarrubias, Sebastián de Covarrubias, Diego Saavedra Fajardo, Andrés Ferrer de Valdecebro, Juan Francisco Villava, Juan de Solórzano y Francisco Núñez de Cepeda. 
las Imprese sacre (Empresas sagradas), inmensa enciclopedia predicable compuesta por el teatino Paolo Aresi.

\section{LAS IMPRESE SACRE DE PAOLO ARESI}

Paolo Aresi o Arese (Cremona, 1574-Tortona, 1644), en el siglo Cesare, procedía de una noble familia milanesa. ${ }^{12} \mathrm{El} 6$ de enero de 1589 ingresó en la orden de los teatinos de San Antonio de Milán, y el 24 de junio de 1590 cambió su nombre por el de Paolo. Enviado a Nápoles a impartir Teología y Filosofía, fue ordenado sacerdote el 19 de octubre de 1598. Su fama como predicador le llevó a recorrer las principales ciudades italianas, hasta que el 20 de julio de 1620 el papa Pablo $\mathrm{V}$ lo nombró obispo de la diócesis de Tortona, dignidad que desempeñará durante 24 años. A su muerte el 14 de junio de 1644, sus exequias fueron celebradas en la iglesia milanesa de San Antonio, con oración fúnebre a cargo del también teatino Giuseppe Cicala. ${ }^{13}$

Desde el instante mismo de su nombramiento episcopal, Aresi se dedicó activamente al cuidado espiritual de su diócesis, con la convocatoria frecuente de sínodos diocesanos, las continuas visitas pastorales y su ardiente predicación en las grandes celebraciones religiosas. Precisamente a la preparación de materiales para la predicación dedicó buena parte de sus obras, entre ellas las Imprese sacre, que lo muestran, además de como un eminente teólogo, como un gran erudito con notables conocimientos humanísticos y científicos. ${ }^{14}$

Ya en el último libro del Arte di predicar bene (Venecia, 1611), anunciaba al lector que se encontraba preparando una colección de empresas que resultaría útil a los predicadores a la hora de componer sus homilías. ${ }^{15}$ Sin embargo, la recopilación no parece haber tenido, en sus inicios, un carácter sistemático, sino que obedece a diferentes momentos cronológicos. La primera edición de las Imprese sacre (Verona, Angelo Tamo, 1615), ${ }^{16}$ comprende únicamente un libro de contenido teórico, en el que a lo largo de 27 capítulos el obispo se esfuerza por definir el origen, arte y naturaleza de las empresas, y proporcionar reglas para su perfecta composición. Nos encontramos ante un texto que, si bien no propone todavía materia predicable, resulta de gran interés desde el punto de vista de la teoría emblemática, convirtiéndose en un completo tratado en el que son continuas las citas a aquellos autores que se han interesado por el tema, caso de Ercole Tasso, Scipione Bargagli, Paolo Giovio,

12 Para los datos biográficos de Paolo Aresi, véase Andreu, F. 1962. "Arese (Aresi), Paolo», en Dizionario biografico degli italiani, Vol. 4: 84-85. Roma: Istituto della Enciclopedia Italiana.

13 Cicala, G. 1644. Oratione detta in S. Antonio di Milano a di 20 di giugno 1644 nelle esequie di monsignor Paolo Aresi, vescovo di Tortona, teatino. Milano: Roda in Porta Romana.

14 Para la precisa contextualización de la obra de Aresi en el marco de la oratoria sagrada de su época, resulta fundamental el trabajo de Ardissino, E. 20 01. II Barocco e II Sacro. La predicazione del teatino Paolo Aresi tra letteratura, immagini et scienza. Città del Vaticano: Libreria Editrice Vaticana. La misma autora había llevado a cabo previamente una aproximación a las Imprese sacre en Ardissino, E. 1998. "Immagini per la predicazione: le imprese sacre di Paolo Aresi». Rivista di Storia e Letteratura Religiosa XXXIV: 3-25.

15 Ardissino, E. 2001: 185.

16 Algunos autores mencionan una edición anterior que vio la luz en Verona en 1613. Sin embargo, E. Ardissino señala la de 1615 como primera edición. Ardissino, E. 2001: 207.
Bartolomeo Taegio, Giovanni Ferro -con quien mantuvo una enconada disputa intelectual- ${ }^{17}$ Girolamo Ruscelli, Giulio Cesare Capaccio, Luca Contile, Scipione Ammirato, Giovanni Andrea Palazzi, Alessandro Farra o Juan de Horozco.

La publicación en Milán seis años más tarde, en 1621, de los libros segundo y tercero -a los que se une la reedición del primero-, comprende las 31 primeras empresas, y constituye la culminación del proyecto inicial de la obra. De hecho, la estructura aparece ya perfectamente definida: primero, las empresas que representan la divinidad y los santos; después, aquellas dedicadas a los virtuosos cuya conducta debe imitarse; por último, las de los viciosos a los que hay que aborrecer. Fijémonos que no se tratan virtudes y vicios como conceptos abstractos, sino personalizados. A su vez, los argumentos vienen a cubrir prácticamente todos los asuntos predicables, desde las celebraciones del calendario litúrgico, hasta las grandes festividades de Cristo, la Virgen y los santos.

Aunque en la introducción a la edición milanesa de 1621 Aresi confesaba su propósito de dar en breve un nuevo volumen a la imprenta, será sin embargo a lo largo de esta década cuando se geste el segundo proyecto de las Imprese sacre. Forman parte del mismo los libros cuarto (dividido en dos partes) y quinto, publicados ambos en 1630, y el libro sexto, también en dos partes, cuya publicación se retrasó hasta 1634-1635 debido a la peste que azotó a toda la región; de dicho retraso y de las causas que lo motivaron, así como de la aparición de un séptimo libro de empresas titulado La retroguardia ${ }^{18}$ daba noticia el impresor a los lectores a la conclusión del libro quinto.

Tal y como recoge el título de la obra, estas «ingeniosas invenciones» están destinadas "a los predicadores, a los estudiosos de la Sagrada Escritura, y a todos aquellos que disfrutan de las empresas y de las bellas letras». En su denominación de Imprese sacre, Aresi considera que no existe para ello una razón mística ni teológico-simbólica, sino por haberlas compuesto a partir de las Sagradas Escrituras, para el fruto de las almas. El teatino define la empresa como «una composición de figura y lema que, trascendiendo su propio significado literal, se destina a representar metafóricamente un concepto particular y concreto". ${ }^{19}$

En realidad, cada empresa está compuesta por tres elementos, en cuya configuración es perceptible la fusión de las tradiciones literarias de emblemas y empresas. El primero de ellos es el lema o mote, enunciado en primera o tercera persona, y extraído en la mayoría de las ocasiones de la Biblia, ya sea literalmente o con una mínima reelaboración; en nuestro estudio le hemos dedicado particular atención, localizando la fuente de la que procede, para comprobar así el ingenio de Aresi a la hora de vincular la Sagrada Escritura con la imagen y enseñanza que propone en la empresa. El segundo elemento es el dibujo o pictura, para el que considera válido cualquier objeto, animal o planta, no así la figura

17 Praz, M. 1989. Imágenes del Barroco (estudios de emblemática): 206-207. Madrid: Ediciones Siruela. Ardissino, E. 2001: 193-194.

18 Este séptimo libro de empresas fue publicado en Génova en 1640.

19 Se trata de una de las definiciones que mejor se ajusta al concepto de emblema, a juicio de Díaz de Bustamante, J. M. 1996. "Sobre los orígenes del emblema literario: lemmata y contexto», en S. López Poza (ed.), Literatura emblemática hispana. Actas del I Simposio Internacional: 64. A Coruña, Universidade da Coruña. 
humana. Finalmente, un epigrama o composición poética, con preferencia una octava de rima $A B A B A B C C$-hay no obstante excepciones-, a la que sigue una extensa subscriptio o declaración en prosa dividida en tres discursos: el primero con las características de la figura, el segundo con la doctrina y aplicación moral de la misma, y el tercero con la interpretación teológica y filosófica concerniente al asunto.

Este esquema de la subscriptio, que Aresi desarrolla en los libros segundo y tercero, varía ligeramente a partir de 1630, por cuanto el discurso que acompaña a las empresas deja de ser triple para convertirse en único, repartido en sucesivos puntos. En el Prólogo al Lector del libro cuarto, reconoce haberse visto obligado a adoptar este cambio por el elevado número de empresas elaboradas -fueron un total de doscientas- y por las continuas ocupaciones de su cargo, que le impedían dedicar más tiempo a la escritura.

Mas con independencia de ello, en todos los casos el lector encuentra abundantes reflexiones útiles, apoyándose en la pictura que protagoniza la escena -de ella, como si de una estructura radial se tratase, surgen múltiples imágenes secundarias- y confiriendo naturaleza visual a las ideas; de ahí su aprovechamiento en el púlpito a la hora de materializar los conceptos de la mente según las técnicas de persuasión propias de la época. El propio Aresi comprueba la eficacia de este método, por cuanto en sus sermones se sirve de imágenes figuradas que propone continuamente a los ojos y oídos del auditorio, tratando de avivar su interés mediante estímulos visuales. De esta manera, la transmisión y memorización de la enseñanza moral, fundadas en la imagen sugerida por el predicador, resultan mucho más sencillas.

El texto se completa con unos copiosísimos índices, dedicados a los lugares de la Biblia citados, a la aplicación de las materias contenidas en las empresas para el tiempo litúrgico y fiestas del año, y a las personas y objetos, virtudes y vicios tratados en el libro. Este conjunto de tablas convierte a las Imprese sacre en un útil instrumento especialmente indicado para fines homiléticos, por cuanto facilita en gran medida la búsqueda temática.

Desde el punto de vista formal, la mayor parte de los grabados que configuran las empresas de Aresi son obra del artista milanés Giovanni Paolo Bianchi. ${ }^{20}$ En algunos casos, el marco en el que se inscribe la pictura no es meramente decorativo, sino que guarda estrecha relación con ella, dando lugar a una figuración más compleja con un significado añadido; así ocurre, por ejemplo, en las empresas dedicadas a san Pedro, san Pablo, san Juan Evangelista, san Sebastián, santo Tomás de Aquino, a la mujer vanidosa y al hombre perezoso. Por su parte, ya hemos indicado que la figura humana no es considerada por Aresi motivo de sus empresas; no obstante, aparece de forma excepcional en la 190 de la segunda parte del libro sexto dedicada a los bebedores y a la crítica de la embriaguez, la cual con el mote Donec impleatur («Hasta que se llene») muestra un brazo humano al que se le está practicando una sangría mediante sanguijuelas. Esta es la única empresa realmente representativa de la figura humana, por cuanto en otros casos resulta testimonial o secundaria.

20 Borroni, F. 1968. "Bianchi, Giovanni Paolo», en Dizionario biografico degli italiani, Vol. 10: 122-123. Roma: Istituto della Enciclopedia Italiana.
PRESENCIA DE LAS IMPRESE SACRE DE PAOLO ARESI EN LA ORATORIA SAGRADA ESPAÑOLA

En nuestro recorrido por la oratoria sagrada española, las alusiones a las Imprese sacre de Paolo Aresi supera de largo el centenar, cifra ciertamente inferior a la de los grandes repertorios de Valeriano o Picinelli, pero demostrativa de que no nos encontramos ante la cita aislada o puntual. Tal constatación nos permite concluir que sus empresas fueron conocidas y utilizadas por los oradores sagrados españoles, los cuales se refieren a su autor en términos elogiosos, tales como «el erudito Aresio», "el ingenioso Aresio», "el doctísimo e llustrísimo Aresio», o con expresiones como "lo explica divinamente el obispo Aresio...». Observemos que, en la castellanización del apellido, este adquiere una "o» final, particularidad que hemos decidido respetar en los textos originales.

El conocimiento de las Imprese sacre en España resulta, además, extendido, tanto en el tiempo como en el espacio. En efecto, comprobamos que la primera referencia a la obra del obispo italiano se fecha en 1638 , es decir, muy pocos años después de la publicación del libro sexto, lo cual pone de manifiesto la rapidez con que se difundió. A partir de esta primera mención, su presencia aumenta y se mantiene constante a lo largo de la segunda mitad del siglo XVII y gran parte del XVIII, hasta alcanzar el año de 1790, última referencia cronológica que hemos encontrado, amén de posteriores reediciones. Al anterior marco cronológico se une el geográfico, por cuanto hacen uso de él predicadores que elaboraron o pronunciaron sus sermones en ciudades como Madrid, Barcelona, Valencia, Zaragoza, Huesca, Toledo, Salamanca, Valladolid, Sevilla, Granada, Córdoba, Málaga, Cádiz, Jaén, Palma de Mallorca y Pamplona, entre otras.

Ciertamente, no en todos los casos estamos ante el manejo directo del libro de Aresi, dado que algunos oradores tuvieron conocimiento de él a través del ya citado Mondo simbolico de Picinelli, que incluye innumerables referencias a las empresas del obispo de Tortona. ${ }^{21}$ Con todo, hemos decidido no hacer distinciones entre uno y otro por cuanto, con independencia de la vía de acceso, el aprovechamiento del material emblemático es evidente, y no falta además en los oradores una alusión personal a su autor.

A la hora de analizar la presencia e integración de las empresas de Aresi en el discurso homilético, resulta preciso hacer una serie de observaciones. En ocasiones no pasa de ser una mera exhibición erudita que apenas si afecta al discurso general del predicador y le sirve en todo caso para captar la atención de un público más instruido; en otras, sin embargo, se inserta de lleno en su argumentación, contribuyendo de forma nítida a su explicación. Debemos significar igualmente que, con cierta frecuencia, el orador hace un uso literal de la empresa de Aresi, es decir, la propone a su auditorio con el mismo significado con el que aparece en el libro del obispo italiano; pero también hay casos en los que se aparta del sentido original para desarrollar una interpretación personal, atribuyendo a la pictura un nuevo significado acorde con

21 Para la composición del Mondo simbolico, Picinelli consultó la obra de diversos autores que habían publicado colecciones de emblemas y empresas, la mayoría italianos, y también algunos españoles, caso de Juan de Horozco y Diego Saavedra Fajardo. Gómez Bravo, E. 1997. "Picinelli en español», en El Mundo Simbólico. Libro I. Los cuerpos celestes: 22-23. Zamora (México): El Colegio de Michoacán. 
la catequesis que desarrolla. Asistimos entonces a una reelaboración de la empresa, aspecto digno de mención por lo que supone de aportación personal de los predicadores hispanos.

Encontramos además una cierta reiteración en el uso de determinadas empresas, lo cual nos habla de la predilección de los oradores por imágenes concretas que a su juicio consideraban sumamente apropiadas para incluirlas en su discurso. Por último, el empleo que en ocasiones hace el predicador de una empresa de Aresi no se refiere al motivo principal recogido en su pictura, sino que remite a alguna de las imágenes o reflexiones que de forma subsidiaria desarrolla el obispo teatino en la subscriptio.

Las anteriores apreciaciones nos ponen en situación de analizar el uso de las empresas de Paolo Aresi en la oratoria sagrada española de la Edad Moderna. Habiendo abordado ya los sermones dedicados a las festividades marianas y a los santos, ${ }^{22}$ nos vamos a centrar en esta ocasión en aquellos que tienen por materia los textos evangélicos y la enseñanza moral que los oradores extraen de los mismos, articulando nuestro discurso en tres grandes apartados: el nacimiento e infancia de Jesús, la doctrina y enseñanza del Maestro, y su Pasión y Muerte. Los mecanismos de la retórica nos permitirán profundizar en la mentalidad de la sociedad española de la época, así como en sus pautas de comportamiento a la hora de explicar la doctrina cristiana, tomando como referencia las Imprese sacre del obispo de Tortona.

\section{NACIMIENTO E INFANCIA DE JESÚS: MARÍA, JOSÉ Y SAN JUAN BAUTISTA}

Al abordar esta primera etapa de los textos evangélicos, constatamos que uno de los autores que más se distingue en el empleo de las Imprese sacre es el teólogo y latinista Diego Suárez de Figueroa. ${ }^{23}$ Entre los diversos episodios que emblematiza, se encuentra el misterio de la Encarnación del Hijo de Dios; en su discurso, encuentra el mejor ejemplo en la empresa tercera recogida en el libro segundo, dedicada a la Virgen Madre de Dios, que lleva por mote Quia respexit («Porque miró»), palabras extraídas del Evangelio de Lucas: Quia respexit humilitatem ancillae suae ("Porque miró la humildad de su sierva», Lc 1, 48). Muestra su pictura un paisaje costero con un sol resplandeciente que ilumina con sus rayos a una nube frente por frente; esta, al brillar,

22 A esta materia hemos dedicado nuestra atención en Azanza López, J. J. 2012. «Emblemática italiana y festividad hispana: las Imprese sacre del obispo Aresi en las grandes solemnidades de la Virgen y los santos», en R. Camacho, E. Asenjo y B. Calderón (coords. y eds.), Fiestas y mecenazgo en las relaciones culturales del Mediterráneo en la Edad Moderna: 137-162. Málaga: Ministerio de Economía y Competitividad y Universidad de Málaga. También rastreamos la presencia de Aresi en un manuscrito redactado en la segunda mitad del siglo XVII con clara finalidad homilética en Azanza López, J. J. 2015. «Empresas y emblemas en un manuscrito de la Biblioteca Histórica de Santa Cruz (Valladolid)». BSAA arte LXXXI: 137-161.

23 Nacido en el último tercio del siglo XVII, Diego Suárez de Figueroa fue teólogo consultor del cardenal Borja, capellán de honor y teniente de limosnero mayor de Felipe V. Su gran afición a la cultura emblemática lo demuestra el hecho de que él mismo escribiera en 1738 un libro de emblemas por deseo de la Princesa de Asturias, María Francisca Xaviera, más conocida como María Bárbara, a quien está dedicado. Suárez de Figueroa, D. 1738. Camino de el Cielo. Emblemas Cristianas. A devoción y de orden de la Serenissima Señora Doña Maria Francisca Xavier Barbara, Princessa de Asturias. Madrid.

se convierte en espejo que refleja en su interior al astro rey, de manera que a los ojos parece haber dos soles en el firmamento (Fig. 1). Se trata de un fenómeno conocido como parhelio. $^{24}$

FIGURA 1

Imprese sacre, Libro II, empresa 3: Quia respexit

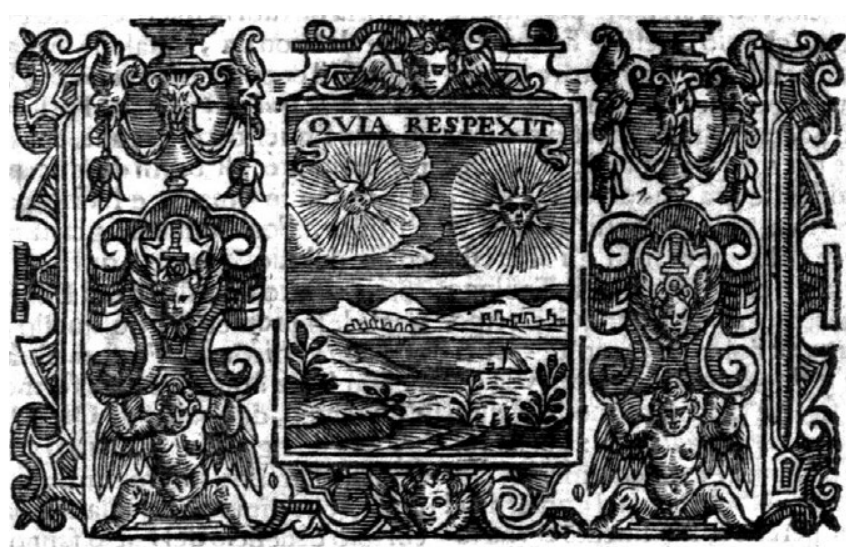

En su razonamiento, Suárez de Figueroa sigue muy de cerca el pensamiento del obispo teatino. Es María nube pura a quien iluminó el divino Sol de Justicia en el misterio de la Encarnación y, con su esplendor soberano, la vistió de luces e hizo semejante a Él; y, al igual que el sol se refleja en la nube y parece estar en su interior, también María, iluminada con singulares virtudes, acogió dentro de sus entrañas al Sol Eterno, revestido de carne humana. Así Dios, con su misma presencia, se dignó asemejar a sí del todo a la Virgen, pues la convirtió al mismo tiempo en su Madre, Esposa e Hija. ${ }^{25}$

A propósito de la pureza y virtud de María en la Encarnación, Suárez de Figueroa introduce una nueva comparación, al señalar que la Virgen se comportó como el árbol púdico. Refiere el religioso que este árbol, criado en ciertas regiones de Brasil, tiene tal antipatía a la vista de los hombres que, en cuanto alguno se acerca y le toca, de inmediato sus hojas se cierran, como si parecieran sentir su presencia; mas, en alejándose, vuelven a desplegarse hasta recuperar su posición inicial. ${ }^{26}$ Así fue también la honestidad y recato de la Virgen María, por cuanto la Encarnación del Verbo no fue obra humana, sino del Espíritu Santo, para

24 Parhelio: fenómeno óptico causado por la refracción de la luz solar, que consiste en la aparición simultánea de varias imágenes del sol reflejadas en las nubes y por lo general dispuestas simétricamente sobre un lado.

25 Suárez de Figueroa, D. 1727b. Vida, excelencias, y muerte del Gloriosissimo Patriarca San Joseph. Escribiola el Maestro Don Joseph de Valdivieso, Mozarabe en la Santa Iglesia e Toledo. Comentala el Doctor Don Diego Suarez de Figueroa. Tomo Segundo: 149. Madrid: en la Oficina de Francisco del Hierro.

26 Suárez de Figueroa, D. 1728a. Vida, excelencias, y muerte del Gloriosissimo Patriarca San Joseph. Escribiola el Maestro Don Joseph de Valdivieso, Mozarabe en la Santa Iglesia e Toledo. Comentala el Doctor Don Diego Suarez de Figueroa. Tomo Tercero: 71. Madrid. En su conocimiento de las propiedades de esta planta, Suárez de Figueroa cita como fuentes al obispo italiano Simón Mayol, al viajero Nicolao Conti (conocido también como Nicolao Veneto) y al «Padre Joseph en la Relación de El Brasil año de 1560", autor y obra que no hemos llegado a identificar. 
manifestar que Cristo vino al mundo por una Virgen Madre que no conoció pecado.

En esta ocasión, el teólogo español se sirve de la empresa 149 del libro quinto de las Imprese sacre, que lleva por mote Non aspiciat me visus hominis («Ni me verá vista de hombre»), extraído con una mínima variante del Libro de Job: Nec aspiciet me visus hominis; oculi tui in me, et non subsistam ( «Los ojos de los hombres no me verán más; fijarás tus ojos en mí, y ya no estaré», Job 7,8$)$. En el cuerpo figura la planta púdica con sus ramas y hojas cerradas (Fig. 2), imagen de la pureza y honestidad de María.

FIGUGA 2

Imprese sacre, Libro V, empresa 149: Non aspiciat me visus hominis

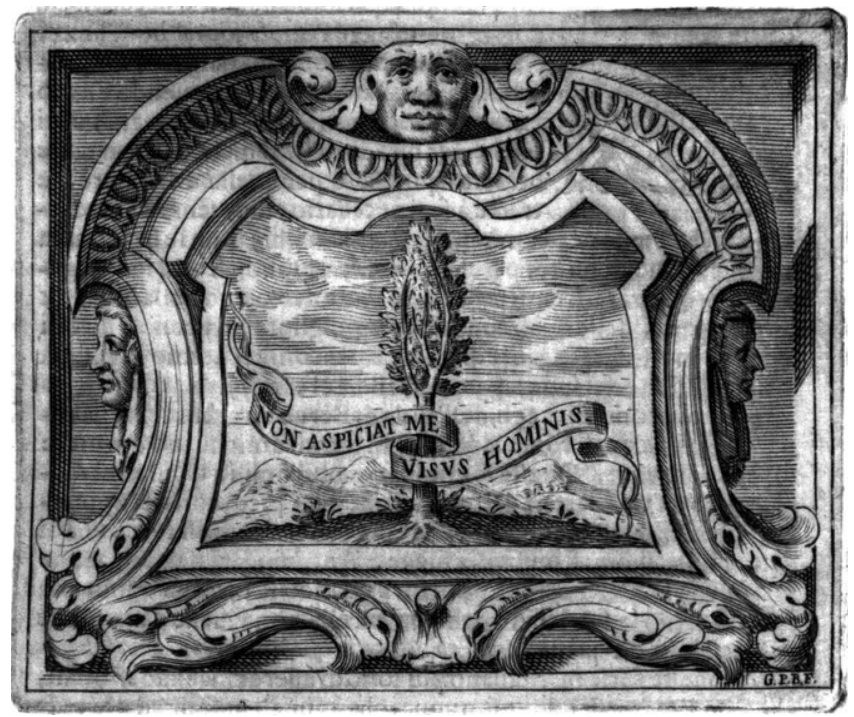

Un nuevo pasaje evangélico recoge la visitación de la Virgen a su prima santa Isabel (Lc 1, 39-56). Significa a este respecto Suárez de Figueroa que, tras ausentarse el arcángel Gabriel, María dispuso su viaje para visitar a su pariente; y desgrana las muchas y muy importantes razones que le movieron a ponerse en camino, como el amor hacia su prima, la asistencia en el parto y la santificación de Juan por Cristo, a quien llevaba en su seno virginal. Por tal motivo, repara en una expresión según la cual esta emprendió el viaje con presteza: Abiit in montaña cum festinatione ("Fue a la montaña con premura»), sin que la detuvieran la comodidad de su casa o las fatigas en su caminar por las montañas. Antes al contrario, la Virgen acudió presurosa, impelida por el Espíritu Santo que, como si de un fuerte viento se tratase, prestó alas a sus pies. ${ }^{27}$

Esa ligereza del caminar de María en su visita a santa Isabel la ejemplifica Suárez de Figueroa en la empresa 126 del libro quinto de las Imprese sacre, que lleva por mote Incedit feliciter («Camina felizmente»), a partir de los Proverbios: Tria sunt quae bene gradiuntur, et quartum quod incedit feliciter («Tres seres son los que andan bien, y el cuarto que camina felizmente», $\operatorname{Pr} 30,29)$. Es precisamente la empresa que dedica Aresi a este pasaje evangélico, y que muestra en su cuerpo una carroza china (Fig. 3), medio

\footnotetext{
27 Suárez de Figueroa, D. 1727b: 327.
}

de transporte impulsado por el viento que empleaban los orientales para desplazarse con mayor rapidez, merced a su vela atada a un mástil. ${ }^{28}$

FIGURA 3

Imprese sacre, Libro V, empresa 126: Incedit feliciter

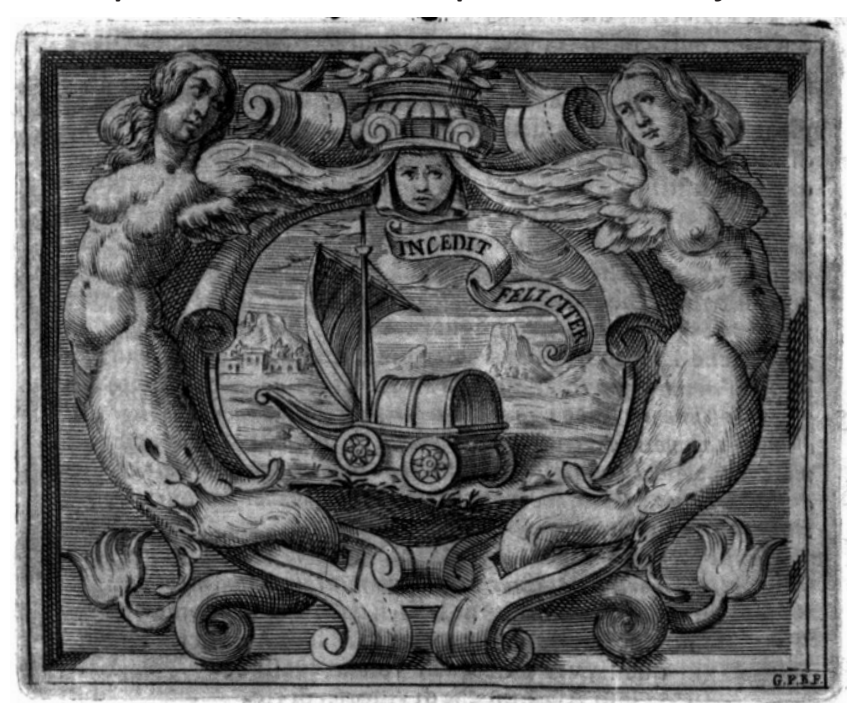

Significa el teatino que estos carros no requieren del arrastre de un hombre, sino que se sirven del viento, por lo que parece que es el cielo el que los guía en su veloz avanzar. Recogiendo la enseñanza de Aresi, concluye Suárez de Figueroa que no fue fuerza humana la que movió a María a visitar a Isabel, sino que le vino del cielo, y de ahí la rapidez con que realizó su viaje, impulsada por el Espíritu Santo.

Si María acudió con ligereza a visitar a Isabel, fue para favorecer tanto a su prima como al niño que llevaba la anciana en sus entrañas. En este último aspecto se detiene el malacitano José Barcia y Zambrana, obispo de Cádiz y uno de los más ilustres predicadores de su tiempo, ${ }^{29}$ quien en 1668 pronunció el sermón de la Visitación en la iglesia parroquial de San Ildefonso de Jaén. En su disertación, afirma que con su presencia, María mostró el camino a seguir al Precursor Juan Bautista, el cual, nada más escuchar su saludo, comenzó a dar saltos en el vientre de su madre

28 Al parecer, ya desde el siglo VI se utilizaban en China carros de vela que se extendían cuando el viento era favorable, de manera que podían desplazarse con mayor rapidez. Así lo certifican, entre otros, el agustino Juan González de Mendoza en el siglo XVı y el dominico fray Domingo Fernández Navarrete en el XVII, si bien este último manifiesta ciertas dudas acerca de su existencia. Con posterioridad, ya en el siglo XIX, Herrera Dávila y Alvear se referirán igualmente a los carros de vela chinos. González de Mendoza, J. 1586. Historia de las cosas más notables, ritos y costumbres del gran Reyno de la China: 18vo. Madrid: en casa de Pedro Madrigal; Fernández Navarrete, D. 1676. Tratados históricos, politicos-ethicos, y religiosos de la monarchia de China: 33. En Madrid: En la Imprenta Real; Herrera Dávila, J. y Alvear, A. 1829. Lecciones de historia del imperio chino. Breve descripción de este Imperio, de su historia, población, gobierno, religión, industria, usos y costumbres: s. p. Sevilla: Imprenta de H. Dávila, Lleba y Compañía.

29 Sobre la figura de José Barcia y el empleo de la literatura emblemática en su predicación, véase Azanza López, J. J. 2013. «Imágenes emblemáticas para el adoctrinamiento regio: los sermones del predicador real José Barcia en la Corte de Carlos I|», Potestas. Revista del Grupo Europeo de Investigación Histórica 6: 255-297. 
(Jn 1, 41). De la misma manera, la Virgen guía a los cristianos por el rumbo cierto hacia el reino de Dios. ${ }^{30}$

Para ejemplificar la imagen de María como guía y camino, Barcia recurre a la empresa 38 de la primera parte del libro cuarto de las Imprese sacre de Aresi. Lleva por mote Iter facit ei, qui ascendit ("Allana el camino, que se eleva»), tomado de los Salmos: Cantate Deo; psalmum dicite nomini eius: iter facite ei qui ascendit super occasum ("Cantad a Dios, celebrad su nombre, allanad el camino al que sube sobre el Occidente», Sal 67, 5). En su pictura podemos apreciar una palmera en medio de un paisaje (Fig. 4). Se percata el obispo teatino de que el tronco de la palmera no es liso como el de otras especies de árboles, sino que se dispone a modo de sucesivos escalones salientes, de manera que trepando por él se pueden alcanzar fácilmente sus frutos. Al igual que el tronco de la palmera actúa como escala que nos permite llegar hasta lo alto, así también Cristo se representa en la palma, pues su santidad permite a los hombres ascender el camino del cielo. La palma es por tanto figura del Señor, y sus méritos y doctrina son otras tantas escalas para ascender al cielo.

\section{FIGURA 4}

Imprese sacre, Libro IV, 1 empresa 38: Iter facit ei, qui ascendit

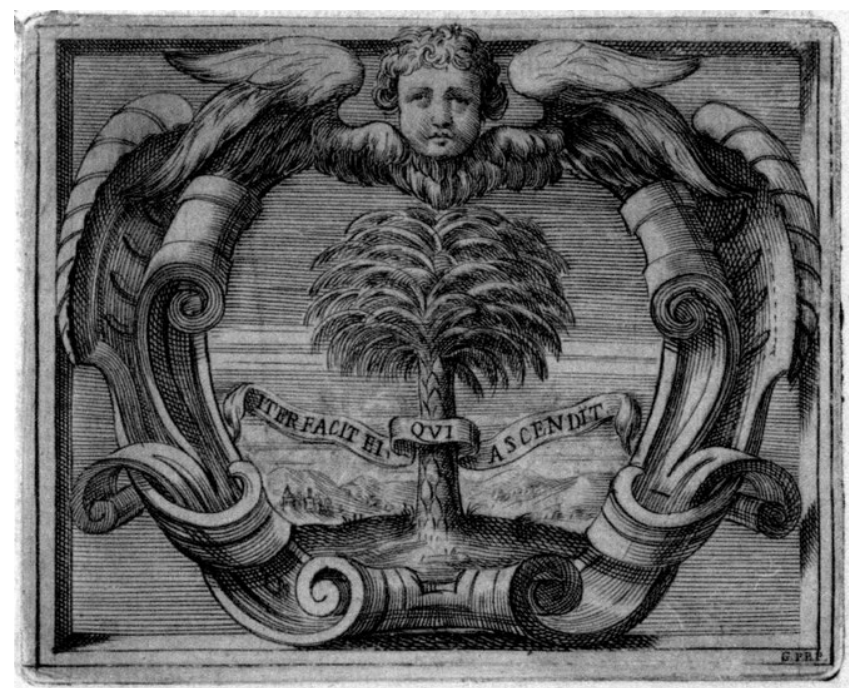

Pues bien, el significado que Aresi aplica a Cristo es traspasado por José Barcia a la «palma sublime» de María que a través de sus méritos, oraciones y ejemplos, facilita el ascenso del hombre hasta la eterna felicidad, al igual que en la Visitación a su prima santa Isabel mostró al Bautista el camino que debía seguir como Precursor de Cristo.

Tras el nacimiento del Mesías, un ángel se aparece en sueños a José, y la Sagrada Familia se pone en camino a Egipto (Mt 2, 13-18). Reflexiona Diego Suárez de Figueroa acerca de los motivos de la Huida a Egipto, y concluye que fue causa de la envidia que se manifestó en Herodes, quien con singular saña buscó al Niño para quitarle la vida. En su exordio acerca de la envidia, el orador la compara con

30 Barcia y Zambrana, J. 1692. Despertador Christiano, Marial, de varios sermones de María Santissima Nuestra Señora en sus festividades: 189. En Madrid: Por Juan García Infanzon. el áspid, pues en sus vivos movimientos se comprueba la furia repentina con que actúa el envidioso, y en la suavidad con que produce su picadura se aprecia la actitud de este, muchas veces lisonjero y adulador con aquel a quien pretende perjudicar. ${ }^{31}$

Áspid de la envidia fue Herodes, primero suave en sus palabras a los Magos, y más tarde rápido en sus movimientos, pues enfurecido al verse burlado, ordenó la matanza de los Inocentes. De ahí la comparación propuesta por el orador español, quien se sirve en esta ocasión de la empresa 165 de la primera parte del libro sexto de Aresi, que lleva por mote Mordet in silentio («Muerde en silencio»), a partir del Eclesiastés: Si mordeat serpens in silentio, nihil eo minus habet qui occulte detrahit («El que de otro dice mal en secreto, no es menos que una serpiente, que muerde en silencio", Ec 10, 11). En la pictura observamos un áspid que avanza retorciendo su cuerpo en medio de un paisaje (Fig. 5).

FIGURA 5

Imprese sacre, Libro VI, 1, empresa 165: Mordet in silentio

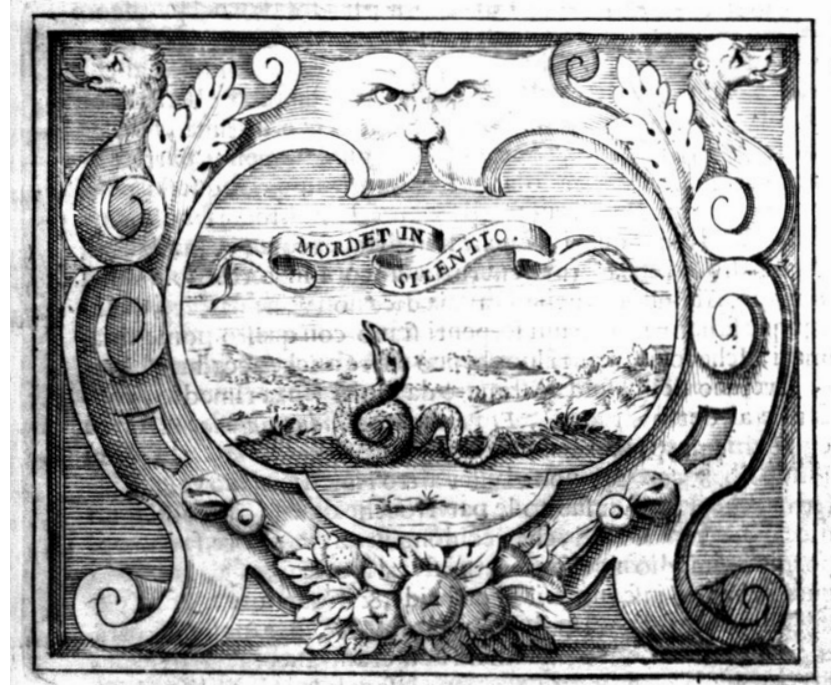

Para el obispo teatino, el áspid es imagen del médico homicida, por cuanto, al igual que el reptil clava sus colmillos con suavidad y el veneno se extiende por el cuerpo del hombre sin que este lo advierta, así también el médico inepto es capaz de causar daño al cuerpo humano con suma facilidad. Aun manteniendo algunos puntos de contacto en su argumentación, Suárez de Figueroa se aparta del significado de Aresi para proponer su propia explicación de la imagen, en relación con Herodes y la Huida a Egipto.

Centrando nuestra atención en un nuevo pasaje evangélico, María cumplió con el rito de la purificación en el templo, según prescribía la ley de Moisés (Lc 2, 22). Asevera Diego Suárez de Figueroa que la Encarnación del Hijo de Dios no guardó el orden de la naturaleza, por cuanto fue obra milagrosa del Espíritu Santo; en consecuencia, la Virgen no necesitaba de la purificación, ya que en el parto no hubo mancha alguna. Entonces, ¿por qué acudió al templo?, se pregunta. Lo hizo

31 Suárez de Figueroa, D. 1728b. Vida, excelencias, y muerte del Gloriosissimo Patriarca San Joseph. Escribiola el Maestro Don Joseph de Valdivieso, Mozarabe en la Santa Iglesia e Toledo. Comentala el Doctor Don Diego Suarez de Figueroa. Tomo Cuarto: 69-81. Madrid. 
para dar ejemplo de humildad y obediencia. María mantuvo siempre hermosa su pureza, pero quiso someterse a la purificación para manifestar un comportamiento humilde y obediente a la ley de Dios, como ejemplo para todos los cristianos. ${ }^{32}$

El mejor símbolo de semejante actitud se encuentra, a juicio del teólogo español, en el cisne. ${ }^{33} \mathrm{Y}$, en concreto, se sirve de la empresa 129 del libro quinto de las Imprese sacre, cuyo lema reza: Qui est mundus totus («Quien está completamente limpio»), inspirado con ligeras variantes en el Evangelio de Juan: Dicit ei Jesus: Qui lotus est, non indiget nisi ut pedes lavet, sed est mundus totus («Entonces dijo Jesús: El que se ha bañado solo necesita lavarse los pies, porque está completamente limpio», Jn 13, 10). La pictura muestra un hermoso cisne nadando en las aguas de un estanque (Fig. 6). Aresi lo propone con el mismo significado de la purificación de María en el templo, y los argumentos son similares en ambos casos. El cisne destaca por el brillante color blanco de su plumaje que, además, no varía con las estaciones, de ahí que se le apliquen continuamente los adjetivos de niveus o albus. Por eso es imagen de candor y pureza, y también de obediencia y fidelidad de ánimo, valores aplicados a María.

\section{FIGURA 6}

Imprese sacre, Libro V, empresa 129: Qui est mundus totus

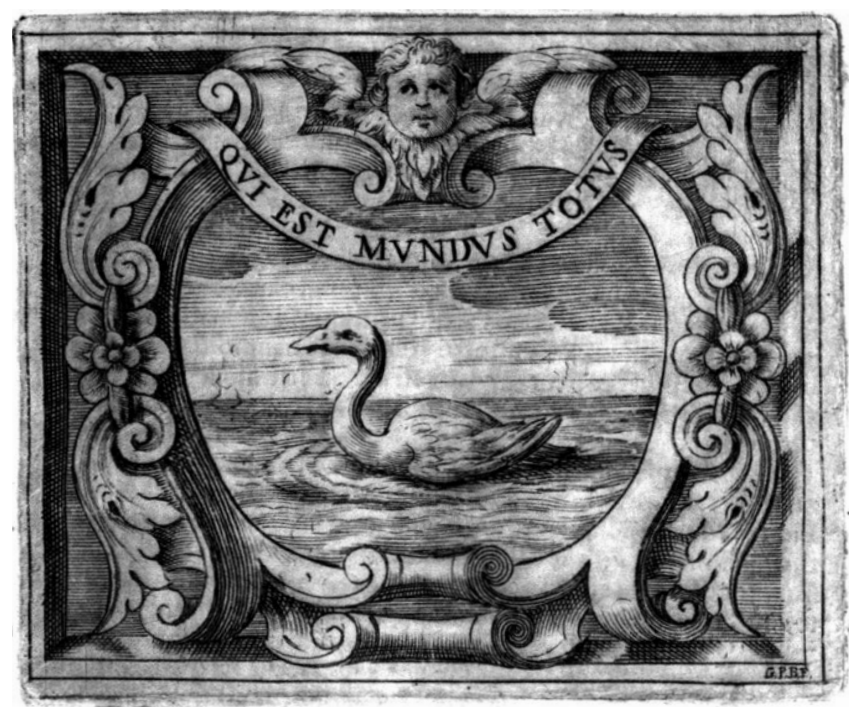

Junto a los anteriores episodios de la vida de la Virgen relatados en el Evangelio, la oratoria sagrada española presta igualmente atención a la figura de José. El 19 de marzo de 1677, José Barcia se dirigía a los fieles de la iglesia del Sacro Monte de Granada, tras haber proclamado el primer capítulo del Evangelio de Mateo. ${ }^{34}$ En el transcurso de

32 Ibídem: $30-31$

33 Sobre la fortuna emblemática del cisne y los diversos significados que incorpora, véase García Arranz, J. J. 2010. Symbola et emblemata avium. Las aves en los libros de emblemas y empresas de Ios siglos XVI y XVII: 274-296. A Coruña: SIELAE y Sociedad de Cultura Valle Inclán.

34 Barcia y Zambrana, J. 1694. Despertador Christiano Santoral, de varios Sermones de Santos, de Anniversarios de Animas, y Honras, en orden a excitar en los fieles la devoción de los Santos, y la imitación de sus virtudes: 94. Cádiz: en casa de Christobal de Requena, Impressor de Su llustrissima. su homilía, fue desgranando las virtudes del Santo Patriarca, a quien quedó confiado el cuidado María y de Jesús en la tierra. Asevera Barcia que cumplió su misión siendo justo, y para ilustrar su afirmación se sirve de la empresa 4 del libro segundo de las Imprese sacre, que lleva por mote Onus leve ("Carga ligera»), tomado del evangelista: Jugum enim meum suave est, et onus meum leve («Porque mi yugo es suave y mi carga ligera», $M t 11,30)$. Muestra su pictura la imagen de una vid con sus racimos y sarmientos, que se sustenta y trepa alrededor de una vara firme (Fig. 7). Se trata de la empresa que el obispo teatino dedica a san José.

FIGURA 7

Imprese sacre, Libro II, empresa 4: Onus leve

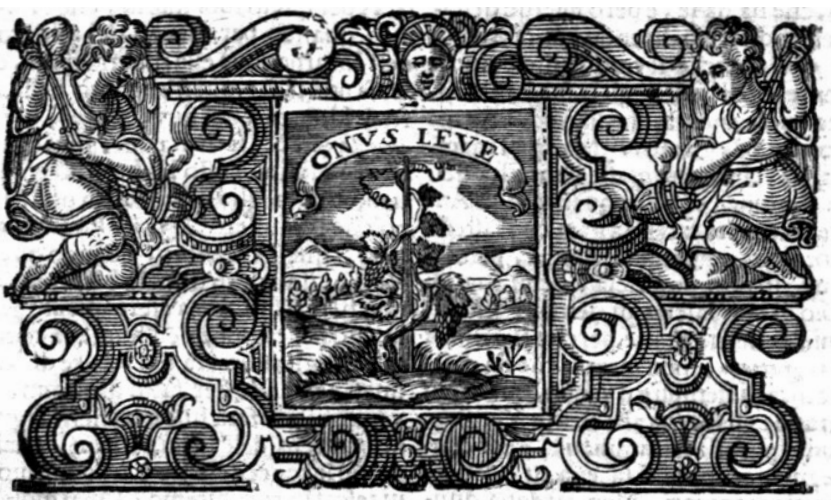

En su discurso, Barcia sigue al pie de la letra la explicación de Aresi: el sarmiento es imagen de María, el racimo de su hijo Jesús, y la vara por la que trepa la vid, de José. Así como la vara sustenta al sarmiento y al racimo, de la misma forma el Patriarca sustentó a María y Jesús; y al igual que el racimo que se apoya en la vara no es fruto de ella, sino de la vid, así también José cuidó del Niño aunque este no fuera hijo natural suyo, sino de María. Cumpliendo por tanto con santa obediencia la misión encomendada, José asistió para crecimiento del racimo divino. La imagen propuesta por Aresi es recogida igualmente por Suárez de Figueroa, para dar a entender que María y Jesús encuentran verdadero apoyo y protección al abrigo del Santo Patriarca. ${ }^{35}$

Mas Suárez de Figueroa se sirve de otras empresas de Aresi para ejemplificar las virtudes y cualidades de san José. Así, significa que fue siempre diligente en el trabajo, vivió honestamente de su oficio de carpintero, y con su esfuerzo y fatiga alimentó a María y al Niño, sin necesidad de ayudas exteriores. ${ }^{36}$ Por tal motivo, considera muy propia del santo la empresa 80 de la segunda parte del libro cuarto de las Imprese sacre, que lleva por mote Labore meo ("Mis trabajos»), tomado del Eclesiastés: Et hanc ratus sum partem meam, si uterer labore meo ( $Y$ Y juzgué que esta era mi recompensa, el disfrutar de todos mis trabajos», Ec 2, 10). Muestra su pictura un águila suspendida en el aire con una presa entre sus garras (Fig. 8), que para Aresi se convierte en imagen de san Agustín, pues así como la reina de las aves no se aprovecha del esfuerzo ajeno, sino que se alimenta tan

\footnotetext{
35 Suárez de Figueroa, D. 1728b: 35.

36 Suárez de Figueroa, D. 1728a: 122.
} 
solo de aquellas presas que captura por sí misma, así también la ciencia que adquirió el obispo de Hipona se debió únicamente a su ingenio. En esta ocasión, el orador español traspasa los méritos de san Agustín a san José, apartándose en consecuencia del sentido original de la empresa.

\section{FIGURA 8}

Imprese sacre, Libro IV, 2, empresa 80: Labore meo

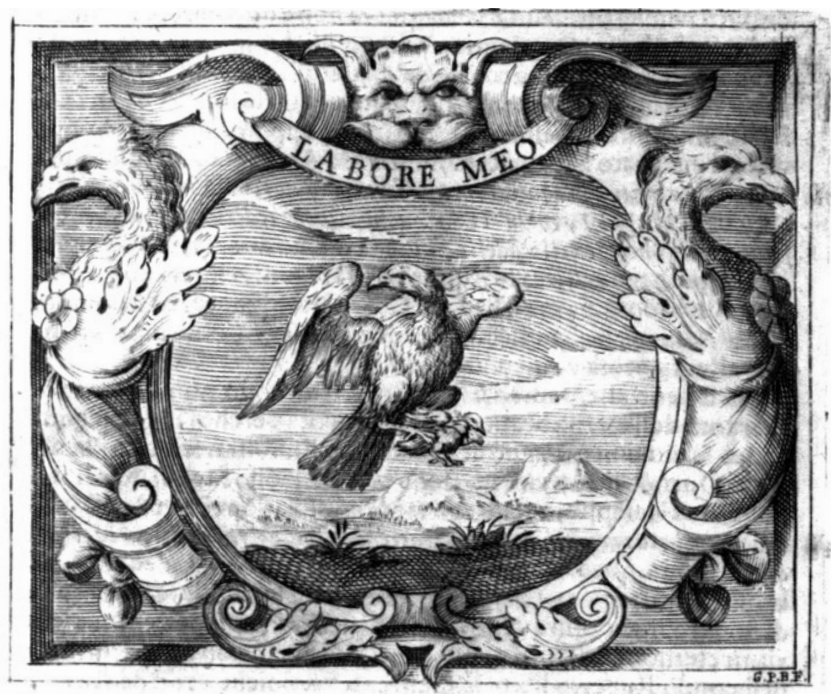

Insiste el orador en que san José trabajó con el esfuerzo y sudor de sus manos, por lo que, "siendo su oficio el de carpintero, para gloria del santo, pongámosle por emblema de su obediencia y de su trabajo la sierra asida de dos manos por los extremos, partiendo un madero, con este mote: Ad dexteram, sive ad sinistram» («Ni a la derecha, ni a la izquierda»). ${ }^{37}$ La imagen propuesta se corresponde con la empresa 94 de la segunda parte del libro cuarto de las Imprese sacre, encabezada por el citado lema tomado del Segundo Libro de los Reyes: Fecitque quod placitum erat coram Domino, et ambulavit per omnes vias David patris sui: non declinavit ad dexteram, sive ad sinistram ("Agradó con su conducta al Señor e imitó el comportamiento de su antepasado David: no se desvió a la derecha, ni a la izquierda», 2 $R 22,2$ ). Tal y como describe Suárez de Figueroa, la pictura muestra una mesa de carpintero en la que una sierra, sostenida por dos brazos en cada extremo, se apresta a cortar una tabla de madera (Fig. 9). Aresi la concibe como empresa del eremita egipcio san Pablo el Simple, que sintió la llamada divina a la vida monástica y se retiró al desierto, distinguiéndose por su extraordinaria humildad y obediencia con las que resistió toda clase de tentaciones, sin desviarse de la recta senda de la virtud.

En la misma línea que san Pablo el Simple, obediencia y trabajo fueron las dos grandes virtudes de san José que permitieron al humilde carpintero llevar una vida recta; y por tal motivo, la imagen de la sierra resulta sumamente apropiada para ejemplificar dicho comportamiento, concluye el orador.

37 Suárez de Figueroa, D. 1728c. Vida, excelencias, y muerte del Gloriosissimo Patriarca San Joseph. Escribiola el Maestro Don Joseph de Valdivieso, Mozarabe en la Santa Iglesia e Toledo. Comentala el Doctor Don Diego Suarez de Figueroa. Tomo Quinto: 397. Madrid.
FIGURA 9

Imprese sacre, Libro IV, 2, empresa 94: Ad dexteram, sive ad sinistram

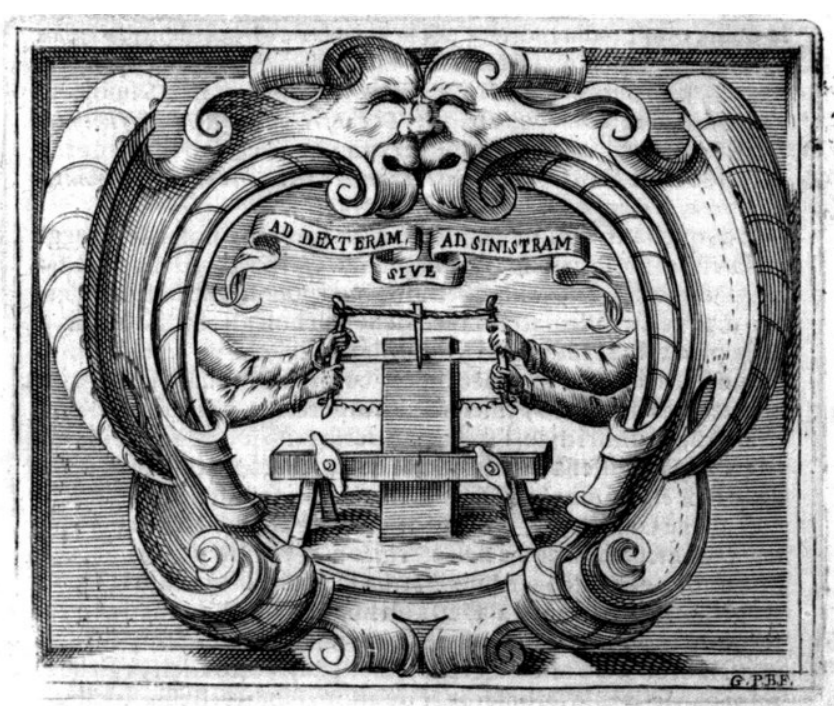

Finalizamos este apartado con una alusión a san Juan Bautista. Refiere Diego Suárez de Figueroa que desde la infancia se retiró al desierto, donde vestía una piel de camello y se alimentaba de miel y langostas; por tal motivo, su vida fue un perpetuo ayuno. ${ }^{38} \mathrm{El}$ orador concreta esta imagen del Bautista penitente, de vida dura en el desierto, en la empresa 49 de la primera parte del libro cuarto de las Imprese sacre, que lleva por mote Non manducans, neque bibens ("No comía, ni bebía») tomado del Evangelio de Mateo: Venit enim Johannes neque manducans, neque bibens, et dicunt: daemonium habet («Porque vino Juan que no comía ni bebía, y dicen: está endemoniado», $M t 11,18$ ).

Muestra su pictura un ave del paraíso, originaria de las Indias Orientales, que aparece remontando su ligero vuelo en medio de un paisaje (Fig. 10) y que Aresi propone como imagen de la vida retirada del Precursor. El razonamiento es común en ambos casos: el ave del paraíso se caracteriza porque ni come ni bebe, de manera que su cuerpo parece carecer de carne y huesos; y tan etérea criatura se encuentra siempre volando, lejos de la vista de los hombres, por lo que lleva a cabo en el aire todas sus acciones sin verse obligada a tocar tierra. ${ }^{39}$

Sin duda, la naturaleza del ave es el mejor ejemplo para ilustrar la sacrificada austeridad y el mundanal alejamiento de san Juan Bautista en el desierto. Precisamente las extraordinarias propiedades del ave del paraíso servirán a otros emblemistas para ilustrar las virtudes de quienes, al igual que el Bautista, se distinguieron por una vida de acentuada austeridad y despegada de los asuntos terrenos, caso de la Virgen María, san Ignacio de Loyola o santa Teresa de Jesús. ${ }^{40}$

38 Suárez de Figueroa, D. 1727b: 374.

39 Sobre el ave del paraíso, su leyenda, naturaleza y propiedades, su presencia en las historias naturales y en los libros de zoología, y su aprovechamiento didáctico, moral y doctrinal en la Edad Moderna, véase García Arranz, J. J. 1996. «Paradisea avis: la imagen de la naturaleza exótica al servicio de la enseñanza didáctico-religiosa en la Edad Moderna». Norba Arte XVI: 131-152; y García Arranz, J. J. 2010: 620-626.

40 García Arranz, J. J. 1996: 146-147. 
FIGURA 10

Imprese sacre, Libro IV, 1, empresa 49: Non manducans, neque bibens

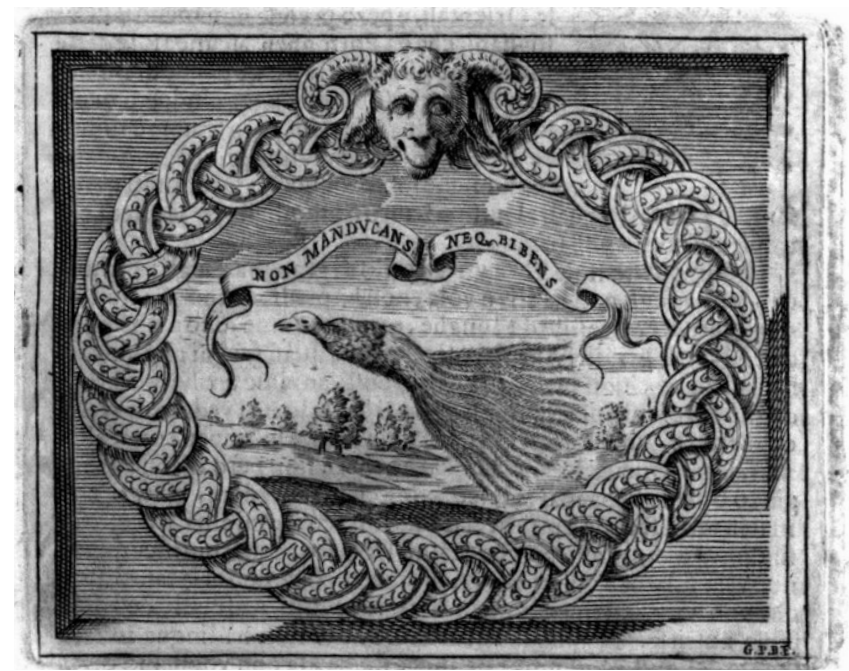

\section{LA DOCTRINA Y MAGISTERIO DE CRISTO}

Alcanzamos así la vida adulta de Cristo. En su magisterio y doctrina, el nuevo mandato del amor al enemigo ( $M t 5$, 43-48) no es un precepto más, sino el centro de todos ellos, al introducir un cambio cualitativo en la práctica de la justicia tal como la entendían los fariseos. El capuchino fray Juan Bautista de Murcia se extiende en una serie de consideraciones a propósito del mandato del Señor que ordena devolver a nuestros agresores bien por mal y orar por quienes nos persiguen; debemos emplear con ellos palabras blandas, las cuales aplacan la ira, mientras que, por el contrario, las ásperas suscitan mayor furor. ${ }^{41}$

Para explicar este comportamiento, el orador propone un símil que tiene su origen en Epitoma rei militaris del escritor romano Flavio Vegecio Renato, tratado militar que dedica especial atención al asedio y defensa de una ciudad. ${ }^{42}$ Según su autor, en la defensa de las murallas contra los arietes y otras máquinas bélicas resultaba muy eficaz la colocación de colchones que, merced a su blandura, amortiguaban el impacto e impedían la destrucción de los muros. ${ }^{43}$

41 Murcia, J. B. 1755. Sermones para todos los domingos del año, y para las ferias mayores de la Quaresma, y asuntos de la Semana Santa. Divídese en dos tomos. Tomo Primero: 177. Barcelona: en la Imprenta de Carlos Sapèra, y Jayme Ofset Libreros.

42 Su redacción obedece al compromiso asumido por encargo directo y personal del emperador Teodosio para que llevara a cabo la ambiciosa empresa de recoger la tradición preceptiva militar romana. La obra consta de cuatro libros: los dos primeros tratan asuntos relativos a la formación, estructura y disciplina militar del ejército romano, el tercero está dedicado a la guerra y a las técnicas del combate terrestre, y el cuarto contempla como tema principal las situaciones bélicas que tienen como escenario la ciudad, al que añade una sección dedicada a los preceptos relativos a la guerra naval.

43 Se trata de un asunto recogido en el capítulo XXIII del Libro IV de Epitoma rei militaris, que dice: "Contra los arietes y las hoces existen muchos sistemas de defensa. Hay quien deja caer centones y colchones atados con cuerdas y los coloca en los puntos donde golpea el ariete para que el impacto de la máquina no destruya la muralla al ser amortiguado con un material muy blando». Vegecio Renato, F. 2006. Compendio de técnica militar (ed. David Paniagua Aguilar): 349. Madrid: Cátedra.
Señala fray Juan Bautista que, a partir de la anterior enseñanza, «el curioso Aresio pintó en sus empresas una ciudad bien murada, y una pieza de artillería, que aunque arrojaba balas, no ofendían a los muros, por estar pendiente de ellos una saca de lana, con esta letra: In molli frangitur» («Pierde la fuerza en lo blando»). En efecto, la empresa 19 del libro tercero de las Imprese sacre lleva tal mote, ligeramente modificado de los Proverbios: Responsio mollis frangit iram; sermo durus suscitat furorem («Respuesta amable calma el furor; palabra áspera excita la ira», $\operatorname{Pr} 15$, 1). Muestra su pictura una pieza de artillería disparando contra una fortaleza, cuyos muros aparecen protegidos por una gran saca de lana atada con cuerdas a la almena superior (Fig. 11). El obispo teatino considera esta táctica defensiva como imagen del hombre manso y pacífico que, ante las ofensas de sus enemigos, no responde con ira, sino que se muestra humilde para detener los ataques y responder con blandura, perdonando a quien le ofende.

FIGURA 11

Imprese sacre, Libro III, empresa 19: In molli frangitur

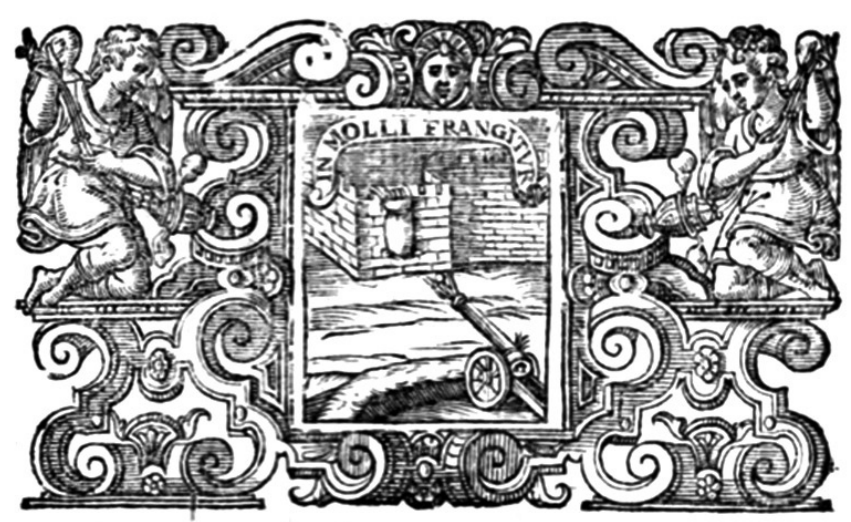

Una vez propuesta la imagen, fray Juan Bautista de Murcia se aplica a la conclusión. Cuando la bala impacta en lo blando, pierde su fuerza y no causa daños; mas cuando pega en lo duro, manifiesta su furor y abre una brecha en la muralla. De la misma forma, las balas de la ofensa con las que atacan nuestros enemigos no nos causarán daño si las aceptamos con mansedumbre, sabiendo perdonar su comportamiento; pero si las recibimos con ira, nos incitarán a la venganza y quedará en nosotros abierta la brecha del odio. Aprendamos por tanto del comportamiento de Cristo, que fue manso y humilde de corazón hasta morir por sus enemigos y perdonar a quienes le crucificaban.

Cristo transmite en muchas ocasiones su doctrina por medio de parábolas. Una de ellas es la de los labradores homicidas que acabaron con la vida de los criados y del hijo del dueño de la viña ( $M t 21,33-46)$, por medio de la cual José Barcia alecciona acerca de la virtud del arrepentimiento en su homilía dirigida en 1680 al Santo Tribunal de la Fe en el convento de Santiago de Granada. ${ }^{44}$ Señala que, por los criados que envía el dueño de la viña a recoger los frutos, debemos entender las tribulaciones que envía Dios a los hombres en forma de guerras, hambres y pestes; se trata

44 Barcia y Zambrana, J. 1697. Despertador Christiano Cuadragesimal de Sermones doctrinales para todos los dias de la Quaresma. Tomo Segundo: 11. Madrid: por Antonio Román. 
de advertencias para que hagamos acto de contrición por nuestros pecados y reformemos nuestras costumbres. Sin embargo, al igual que los labradores no mostraron arrepentimiento alguno por matar a los criados, así también nosotros persistimos en nuestros pecados y culpas, pese a todos los avisos que nos da el Señor.

En su explicación de la falta de arrepentimiento del hombre, Barcia acude a la empresa 27 del libro tercero de las Imprese sacre, que lleva por mote Dissipatae, non compunctae («Rechazadas, pero no arrepentidas»), extraído casi literalmente de los Salmos: Dissipati sunt, nec compuncti ("Son rechazados, pero no se arrepienten», Sal 34, 16). Protagoniza la pictura un enjambre de moscas ahuyentadas por el movimiento de un abanico, pero que, una vez pasado el peligro, vuelven de nuevo a molestar con su vuelo (Fig. 12). Para el obispo teatino, el comportamiento de las moscas es imagen del pecador afligido por las calamidades pero todavía no arrepentido de sus vicios, de manera que sigue obstinado en sus errores.

FIGURA 12

Imprese sacre, Libro III, empresa 27: Dissipatae, non compunctae

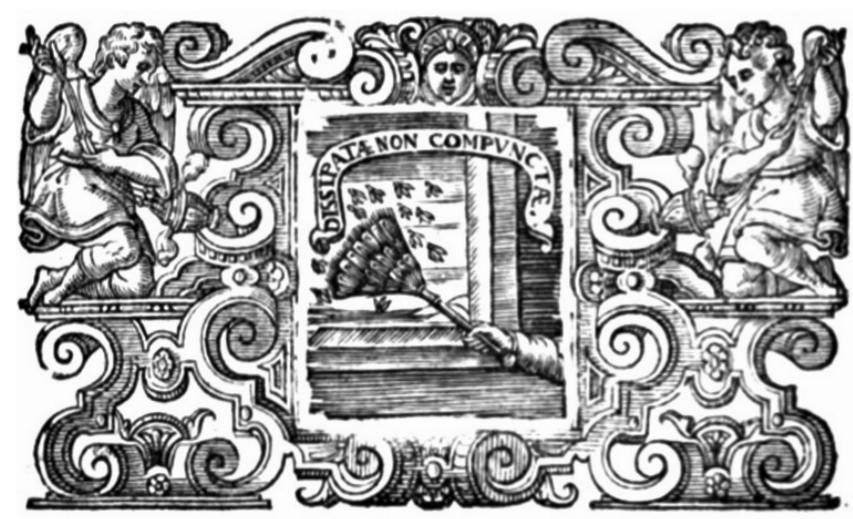

El mismo significado propuesto por Aresi aplica Barcia a la imagen de las moscas, aseverando que así es el comportamiento de los pecadores ante los trabajos y calamidades que ha enviado Dios al mundo. Muchos parecen mostrar arrepentimiento, pero no es sincero sido fingido, pues en cuanto tienen oportunidad vuelven a reincidir en el pecado. Dios nos da muchas oportunidades para abandonar nuestra obstinación en el pecado, y no debemos rechazarlas, sino aprovecharlas, mostrando firme propósito de no caer en él, concluye el predicador.

Un nuevo pasaje evangélico susceptible de emblematización es el de la mujer sorprendida en adulterio, a la que los fariseos llevaron ante la presencia de Jesús (Jn 8, 1-11). El episodio le sirve al franciscano fray Juan Esquirol para moralizar acerca de la necesidad de vivir la castidad matrimonial, y recurre para ello a varios símiles, entre los que se encuentra una empresa de Aresi. Considera que fue el demonio el que indujo a cometer adulterio a la mujer; de hecho, fue Satanás el que, en forma de serpiente, acabó con el estado de felicidad de nuestros primeros padres en el Paraíso Terrenal. Al igual que Eva se dejó tentar por la serpiente y comió del fruto prohibido, así también la mujer adúltera tenía en su interior la serpiente del demonio que le llevó a pecar.
Para mostrar esta actitud negativa, el predicador acude al ejemplo del pez murena que, atraído por el silbido de la serpiente, abandona a su consorte en el mar y se entrega a aquella. Ya los autores antiguos como Aristóteles o Plinio aluden a la afición de la murena por salir del mar a tierra para tener ayuntamiento con la serpiente. Así lo recoge Aresi en la empresa 159 de la primera parte del libro sexto de sus Imprese sacre, en la que, con el mote Alienum adamat ("Ama al extraño»), muestra la desigual unión de la murena y la serpiente como imagen no solo de la relación adúltera, sino también de las religiosas ingratas que incumplen el voto sagrado de estar desposadas con Dios (Fig. 13).

\section{FIGURA 13}

Imprese sacre, Libro VI, 1, empresa 159: Alienum adamat

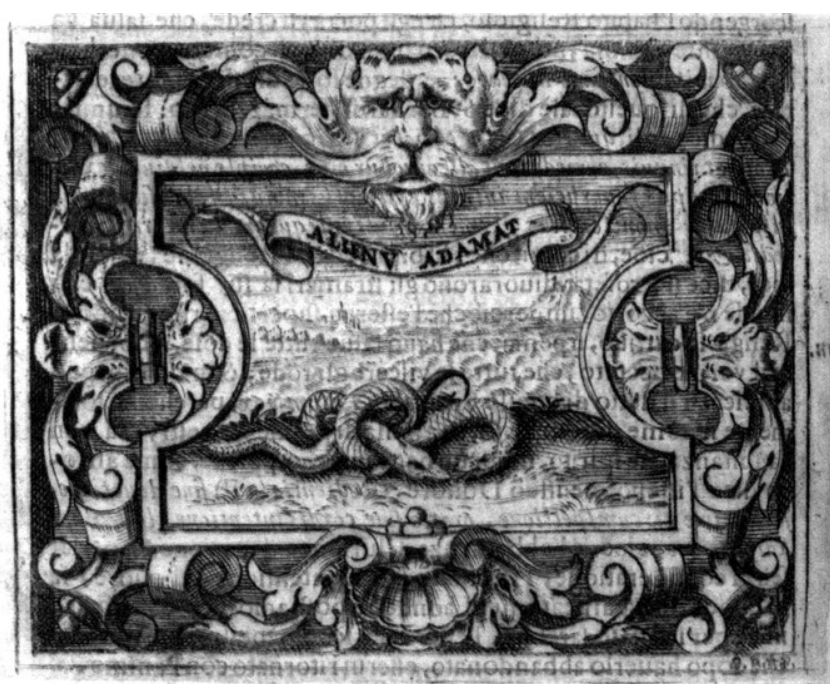

La enseñanza que extrae Esquirol del anterior ejemplo es clara: hay que guardar la fidelidad en el seno del matrimonio, pues, al igual que Eva se dejó engañar por una serpiente y la mujer adúltera actuó inducida por el demonio, así también en ocasiones se interpone la serpiente del demonio entre marido y mujer para romper la armonía conyugal. ${ }^{45}$

Los predicadores se fijan igualmente en la actitud de la madre de los Zebedeos, que solicita a Cristo puestos importantes para sus hijos ( $M t 20,20-28$ ), para adoctrinar contra la soberbia. Significa el carmelita fray Jacinto de Aranaz que, frente a la actitud humilde del Maestro, quien acababa de revelar a sus discípulos las afrentas que iba a padecer en su misión redentora, la madre de Santiago y Juan se arrodilló para pedir los mejores puestos para sus hijos. Alude el orador al ingrato comportamiento de los ambiciosos, quienes no dudan en mostrarse humildes a la hora de pedir, arrodillándose ante aquellos a los que solicitan cargos y honores; pero, una vez obtenido lo que desean, se levantan soberbios, dejando al descubierto su fingida humildad. ${ }^{46}$

45 Esquirol y Murillo, J. 1727. Didascalia Evangélica y Cuadragesimal, para todas las ferias, mayores, y menores, de la Cuaresma: 272-275. Zaragoza: en la Imprenta de Pedro Ximénez.

46 Aranaz, J. 1713. Quaresma continua. Primera parte de Sermones en las Ferias Mayores: 422. Pamplona: en el Real Convento de Nuestra Señora del Carmen. 
El mejor ejemplo del ambicioso se encuentra, a su juicio, en la empresa 24 del libro tercero de las Imprese sacre, protagonizada por un camello que se arrodilla y dobla las patas delanteras para recibir la carga (Fig. 14) acompañado del mote Donec accipiat («Espera con paciencia»), tomado de la Carta de Santiago: Ecce agricola exspectat pretiosum fructum terrae, patienter ferens donec accipiat temporaneum et serotinum ( "Ved cómo el labrador aguarda el fruto precioso de la tierra, esperando con paciencia las lluvias tempranas y tardías", Stg 5, 7). Para Aresi, el camello es imagen del ambicioso que, para alcanzar lo que pretende, se muestra sumiso en sus palabras y acciones, pero tras alcanzar su propósito, se yergue altivo sin acordarse de quien le hizo el favor y socorrió en el aprieto; pues es condición del hombre ser humilde al pretender, y volver luego las espaldas del agradecimiento al benefactor. Con el obispo coincide el predicador español, quien asevera que hay que abandonar la soberbia, por ser contraria a la doctrina de Cristo.

\section{FIGURA 14}

Imprese sacre, Libro III, empresa 24: Donec accipiat

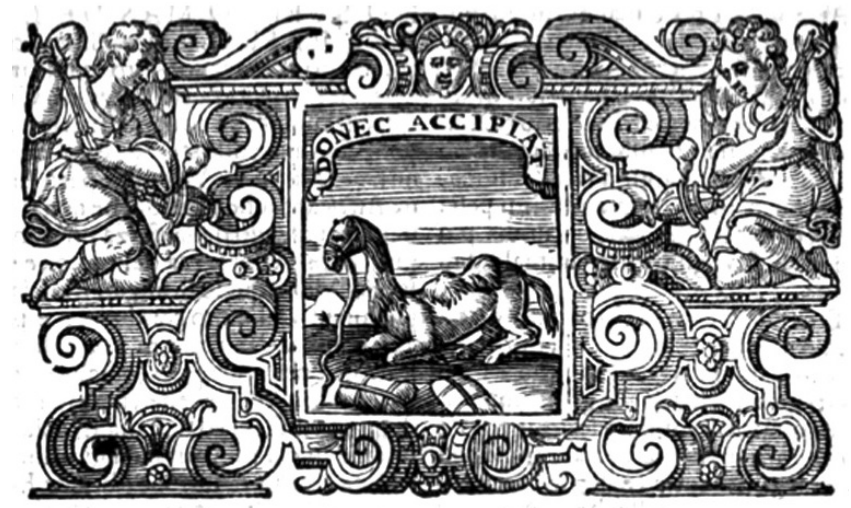

El mismo razonamiento de fray Jacinto de Aranaz había empleado décadas atrás fray Diego Niseno, predicador de la orden religiosa de los Basilios, a propósito del hombre soberbio y ambicioso que, una vez logrado su propósito, se muestra áspero e ingrato con quien le ayudó, ya haya obtenido el favor humano o el divino: "Camellos torpes y feos son esta mala raza de ruin gente, que pidiendo parecen más humildes que su propia humildad, y en consiguiendo son más villanos que la misma rustiquez», concluye el orador. ${ }^{47}$

\section{PASIÓN Y MUERTE DEL SEÑOR}

También los pasajes de la Pasión y Muerte de Cristo son susceptibles de emblematización en la oratoria sagrada española, tomando como referencia las Imprese sacre Aresi.

El momento del Prendimiento y el consiguiente comportamiento de los discípulos, que lo abandonaron y huyeron ( $M t$ $26,47-56)$, es motivo de comentario por parte de fray Juan

47 Fray Diego Niseno se remite a la empresa del camello como imagen del hombre soberbio en dos ocasiones: una de ellas, en Niseno, D. 1638. Segunda parte del Político del Cielo. Hallado en las Misteriosas acciones del sagrado patriarca Jacob: 187-190. Barcelona: a costa de Sebastián de Comellas Mercader; y otra, en Niseno, D. 1650. El lucero de la tarde S. Juan, Apostol, Evangelista, y Profeta, en asuntos predicables, morales, esornatorios: 226-227. Madrid: en la Imprenta de María de Quiñones.
Bautista de Murcia. Observa en primer lugar el predicador capuchino el cambio de actitud de los discípulos, quienes en el milagro de la resurrección de Lázaro habían asegurado por boca de Tomás seguirle hasta morir con Él $(J n 11,16)$; y, poco antes del arresto, Pedro y los demás prometieron morir a su lado antes que negarle (Mt 27, 35). Sin embargo, en cuanto ven al Maestro apresado, huyen cobardes y temerosos.

Considera fray Juan Bautista que tal comportamiento es contrario a la imagen de la granada, fruta que, aunque esté abierta, no pierde ningún grano y todos permanecen unidos, símbolo del prelado que mantiene reunidas en torno a sí a sus ovejas. Por tal motivo, en la empresa 112 de la segunda parte del libro cuarto de sus Imprese sacre, Aresi pintó por empresa del beato Andrés Avelino -canonizado por el Papa Clemente XI en 1712- una granada abierta en la que la corteza mantiene unidos sus granos (Fig. 15), con el mote Nec unum cecidit («Ni uno solo falta»), extraído con una ligera variación del Libro Primero de los Reyes: Non cecidit ne unus quidem sermo ex omnibus bonis quae locutus est per Moysen servum suum ("Ninguna de sus promesas, hechas por medio de su siervo Moisés, ha dejado de cumplirse», $1 R 8,56)$.

\section{FIGURA 15}

Imprese sacre, Libro IV, 2, empresa 112: Nec unum cecidit

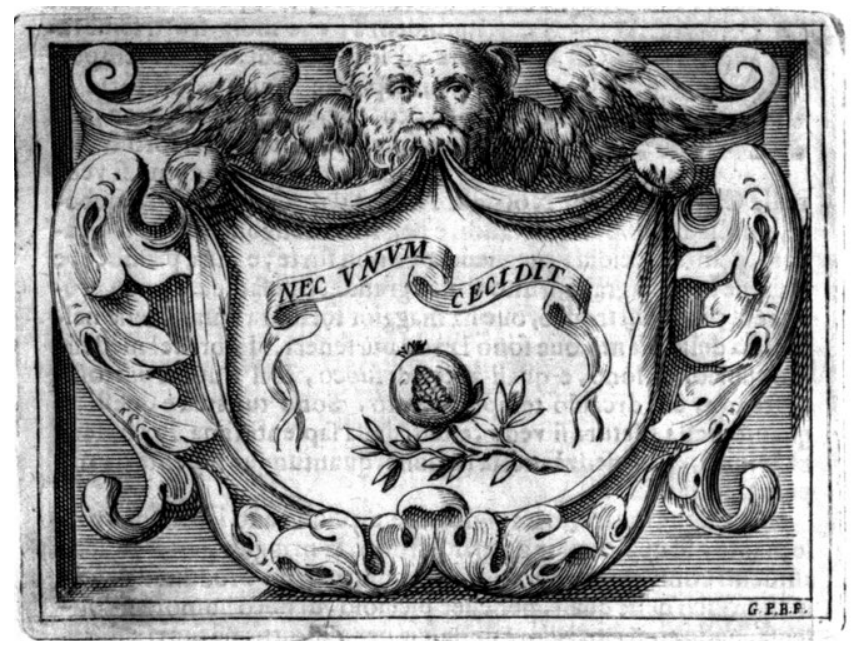

Refiere el obispo teatino que la corteza de la granada tiene cierto parecido con las mejillas del hombre; y así como aquella no deja caer ningún grano, tampoco de la boca de Andrés Avelino salió palabra alguna que supusiera desunión. Antes al contrario, fue tal la diligencia en su labor predicadora que, como superior de diferentes casas de la Congregación, supo unir en torno a sí a los religiosos; y en su vocación apostólica de entrega a los demás, atrajo hacia la Iglesia y mantuvo unidos con Cristo a muchos pecadores.

¡Qué diferente fue el comportamiento de los discípulos, que huyeron y dejaron desamparado al Señor apenas lo vieron en manos de sus enemigos!, refiere el orador capuchino. No actuemos como ellos, sino que seamos fieles al Señor y permanezcamos unidos a Él también en las dificultades, como muestra el ejemplo de la granada. Como podemos comprobar, en esta ocasión fray Juan Bautista de Murcia se aparta del sentido original de la empresa de Aresi, para darle un significado conforme a la doctrina que quiere transmitir en relación con la lealtad y fidelidad de los cristianos hacia Jesús. 
En el momento culminante de la Crucifixión, el dominico fray Jaime Barón se detiene en la contemplación de Cristo clavado en el madero de la Cruz. ${ }^{48}$ Considera que la cruz a la que ascendió el Divino Redentor puede simbolizarse en la palma; y se sirve para ello de la empresa 42 recogida en la primera parte del libro cuarto de las Imprese sacre de Paolo Aresi, que lleva por lema Ad omnia utilis («Para todo es útil»), sentencia extraída de la Primera Carta a Timoteo: Pietas autem ad omnia utilis est, promissionem habens vital, quae nunc est, et futurae ("La religión es útil para todo, pues tiene la promesa de la vida presente y de la futura», $1 \mathrm{Ti}$ 4, 8). Su pictura muestra una palma indiana de dilatadas ramas cargadas de frutos, como símbolo de la cruz en la que murió el Señor (Fig. 16). Siguiendo al pie de la letra el discurso del obispo teatino, nos dice el predicador que se cría en las islas de Maldivia una especie de palma que produce todo lo necesario para el alimento y cuidado de los hombres, por cuanto de ella se extrae no solo aceite, leche y vino, azúcar y miel, sino también sogas e hilo, papel para escribir y para confeccionar vestiduras, vigas y tejas para fabricar casas, y madera para bastones y para construir las naves con las que comerciar en el mar.

\section{FIGURA 16}

Imprese sacre, Libro IV, 1, empresa 42: Ad omnia utilis

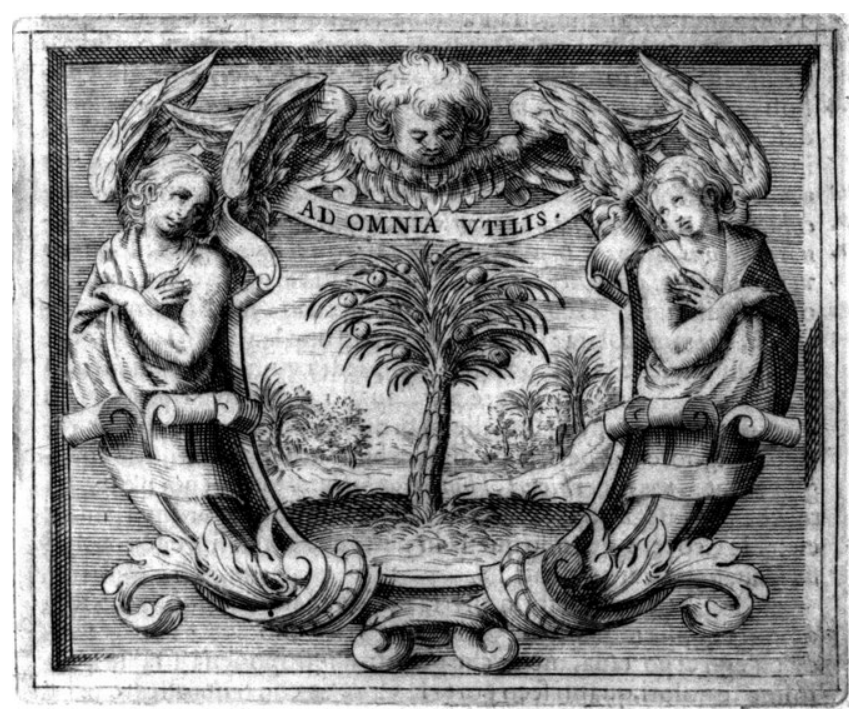

Este maravilloso árbol resulta, por tanto, útil para todo cuanto necesita el ser humano; y es por eso símbolo acertadísimo de la Santa Cruz, o del propio Cristo clavado en ella, tesoro de todos los bienes y riquezas. Es árbol que da frutos de vida eterna con que alimentar nuestra alma; aceite que puesto en la lámpara de la fe disipa las tinieblas del pecado e ilumina nuestro camino; atadura que nos une al Padre Celestial; palabra que sirve para cubrir la desnudez de nuestras culpas; báculo sobre el que el cristiano se sustenta en el camino desde este mundo a la eternidad; y divina embarcación en la que navegamos hacia el puerto de la salvación. Contemplemos pues al Señor clavado en la cruz, porque en esta imagen hallaremos todo cuanto necesitamos en nuestra vida cristiana. Un razonamiento similar, aunque aplicado a la imagen milagrosa del Santo Cristo venerado en la

48 Barón, J. 1790. Luz de la Senda de la virtud, Desiderio y electo en el camino de la perfección. Tercera parte del Segundo Tomo: 512514. Madrid: en la Imprenta de Don Benito Cano. localidad aragonesa de Calatorao, había empleado décadas atrás el agustino fray Diego Gracia en uno de sus sermones. ${ }^{49}$

Estando clavado en la cruz, se produce el diálogo con el ladrón arrepentido que confesó sus culpas, reconoció la inocencia de Cristo y se confió a Él (LC 23, 39-43). En el momento de su muerte, el buen ladrón tuvo el arrojo y la decisión suficientes para rogar al Señor que se acordase de él en su reino. Mas, ¿de dónde sacó las fuerzas en el instante final?, se pregunta fray Juan Esquirol. ${ }^{50}$

Para responder a esta cuestión, el predicador franciscano acude al ejemplo del elefante propuesto por Aresi en la empresa 13 del libro segundo de las Imprese sacre, que lleva por mote Acuor in praelium («Me preparo para la batalla»), variante del Primer Libro de los Macabeos: Et elephantis ostendederunt sanguinem uvae et mori, ad acuendos eos in praelium ("Los soldados abrevaron a los elefantes con zumo de uvas y moras para excitarlos a la lucha», 1 Mac 6, 34). En total coincidencia con el mote, la pictura muestra un elefante ante el cual una mano exprime el jugo de un racimo de uvas, que cae en un recipiente (Fig. 17). Alude el obispo teatino al comportamiento de los elefantes que, a la vista del color rojo del jugo de uvas y moras, cobran mayores fuerzas para el combate. Tal disposición de los paquidermos para la guerra aparece recogida en el mencionado pasaje, según el cual los soldados del ejército sirio pusieron delante de dos elefantes adiestrados para la guerra zumo -literalmente sangre- de uvas y de moras, con el fin de enardecerlos para el combate. En efecto, como testimoniaban los textos antiguos y los bestiarios medievales, el furor guerrero de los elefantes era provocado por la visión del jugo rojo que se les mostraba antes de la batalla.

FIGURA 17

Imprese sacre, Libro II, empresa 13: Acuor in praelium

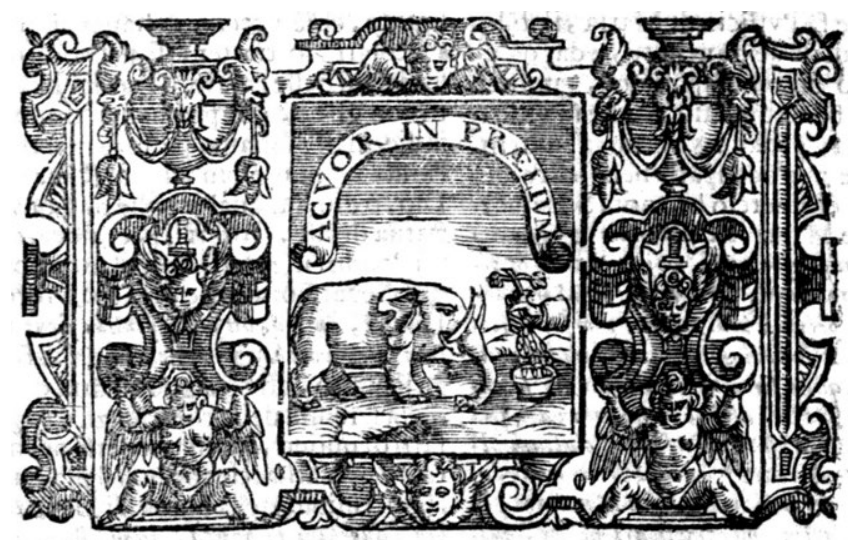

Según Aresi, al igual que el elefante cobra nuevas fuerzas al contemplar el color de la uva, así también la Pasión de Cristo proporciona fortaleza al cristiano; y con el teatino coincide el predicador español, para quien la sangre de Cristo derramada en su Crucifixión perdona nuestras culpas y nos da vigor, sirviendo como escudo del cristiano. Lo mismo ocurrió con el ladrón arrepentido, el cual, bañado en la sangre de Cristo, tuvo energías para entablar el combate de la vida eterna y salir victorioso de él merced a la divina misericordia.

49 Gracia, D. 1711. Sermones de Christo, su Santissima Madre, y algunos de los primeros Santos de la Iglesia: 26-27. Zaragoza: por Manuel Román, Impressor de la Universidad, y de la Santa Iglesia Metropolitana.

50 Esquirol y Murillo, J. 1727: 559-565. 
OTROS EJEMPLOS DE LAS IMPRESE SACRE EN LA ORATORIA SAGRADA ESPAÑOLA

Aunque sin llegar a ajustarse a un pasaje evangélico concreto, en otras muchas ocasiones las Imprese sacre de Aresi sirven a los oradores sagrados para «pintar» con imágenes la doctrina cristiana y concretar la catequesis y enseñanza moral que desean extraer en sus homilías. Hagamos a continuación un rápido recorrido por alguna de ellas.

FIGURA 18

Imprese sacre, Libro VI, 2, empresa 179: In lingua eius labor, et dolor

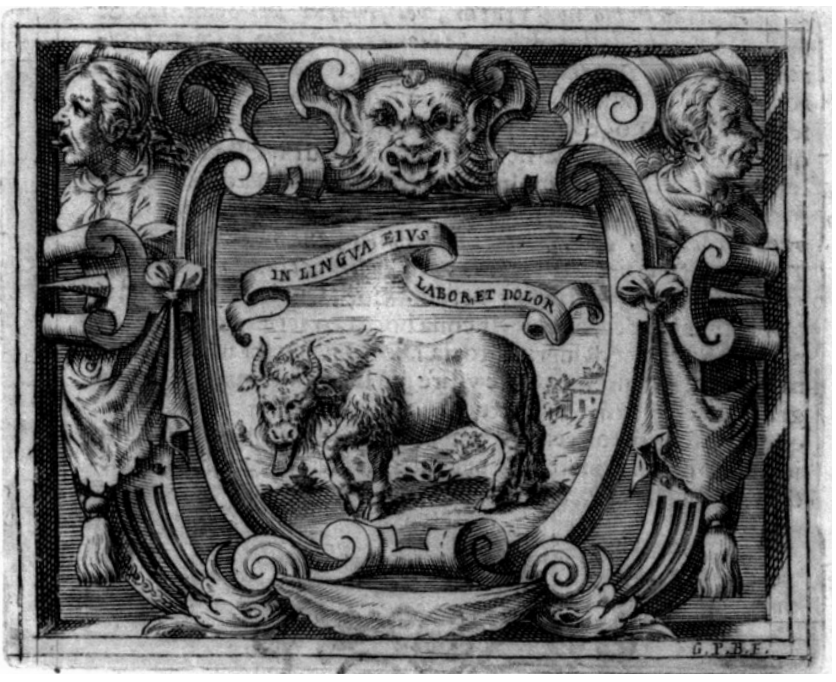

Para fray Jaime Barón, la empresa del bisonte de lengua dura y áspera, que hiere con ella al que toca, se convierte en ejemplo del hombre murmurador o adulador, que daña a aquel de quien murmura (empresa 179 de la segunda parte del libro sexto de las Imprese sacre, que lleva por mote In lingua eius labor, et dolor, "En su lengua hay trabajo y dolor», Sal 10, 7, y Aresi propone con este mismo asunto) (Fig. 18). La del halcón que sujeta con su garra a la liebre que ha apresado, es imagen de la perseverancia (empresa 74 de la primera parte del libro cuarto, Tenui, nec dimittam, "Lo abracé, y no lo soltaré», Cnt 3, 4, dedicada por el obispo teatino al dominico veronés san Pedro Mártir). La del erizo que carga sus púas con frutas con las que alimentar a sus hijos, es ejemplo del hombre benéfico que socorre a los necesitados (empresa 67 de la primera parte del libro cuarto, Immutavit naturalem usum, "Invirtió el uso natural», Ro 1, 26, dedicada a san Sebastián). Finalmente, la empresa del cañón o pieza de artillería inutilizado por medio de un hierro fijado en el suelo, es para Barón metáfora del hombre que tiene clavado el corazón con el hierro del pecado mortal, por cuanto sus buenas obras resultan inútiles y no merecen la vida eterna (empresa 176 de la primera parte del libro sexto, con el mote Ad nihilum valet ultra, "No sirve después para nada», $M t 5,13$, que Aresi propone como imagen del pecador ya virtuoso). ${ }^{51}$

51 Barón, J. 1732. Remedio Universal de todas las necessidades y trabajos, el Rosario de María SSma., Madre de Dios, y de pecadores. Tomo Primero: 98, 176 y 323. En Zaragoza: En la Imprenta Real de Luis de Cueto. Barón, J. 1790: 36 y 275.
Por su parte, la empresa de la hiena que cavando encuentra los cadáveres enterrados en los sepulcros, se convierte para el abad de los Mínimos Cristóbal Gasch en elocuente imagen de los beneficios que proporciona la reflexión sobre la muerte (empresa 81 de la segunda parte del libro cuarto, que con el mote Quasi thesaurum effodiens, "La buscan más que a un tesoro", Job 3, 21, que dedica Aresi a san Jerónimo Doctor de la Iglesia). ${ }^{52}$ Para el franciscano fray Antonio Arbiol, el pavo real es símil de la mujer profana (empresa 186 de la segunda parte del libro sexto, Pulchra, et fatua, "Hermosa, y fatua», $\operatorname{Pr} 11,22$, símbolo de la mujer vanidosa) (Fig. 19). ${ }^{53}$ Para el franciscano fray Francisco de Soto, el lince se convierte en jeroglífico de los ingratos que, olvidando los beneficios recibidos, responden con agravios a sus bienhechores (empresa 59 de la primera parte del libro cuarto, Non memorabor amplius, "No me acordaré más», Jer 31, 34, que Aresi aplica al apóstol Mateo); y la hiedra que abraza el tronco del árbol seco, en imagen de la amistad verdadera (empresa 150 del libro quinto, Necque mors separabit, "Ni la muerte lo separará», variación de Ro $8,35-38$, alusiva a la viuda o casada fiel)..$^{54}$

\section{FIGURA 19}

Imprese sacre, Libro VI, 2, empresa 186: Pulchra, et fatua

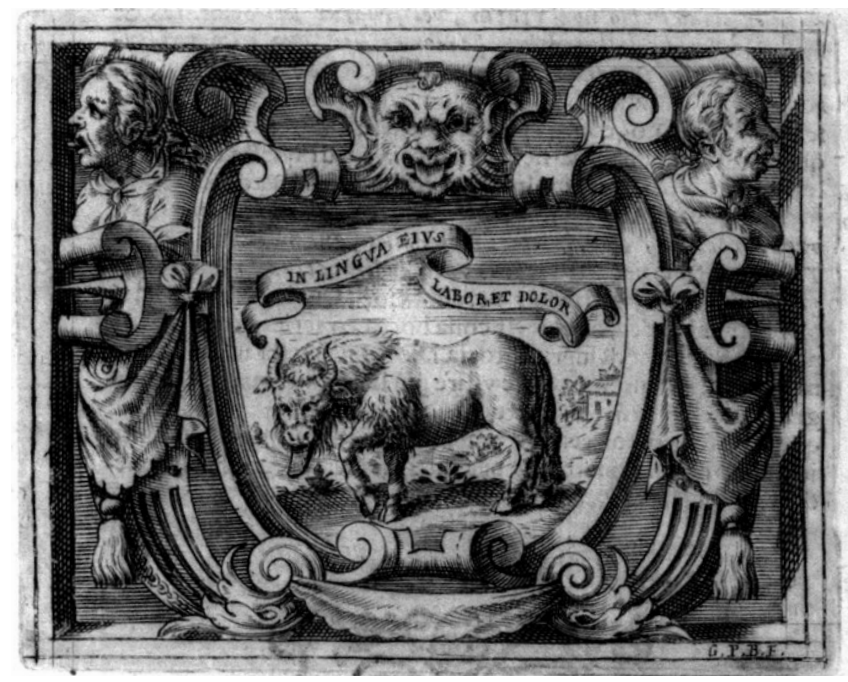

Para Diego Suárez de Figueroa, la empresa del mochuelo contemplando la luna es imagen del amante impuro y lascivo, por cuya ceguera aborrece la luz y no quiere gozar de los resplandores del sol divino, buscando solo la oscuridad de los bienes mundanos (empresa 168 de la primera parte del libro sexto, que con el mote Speciosior sole, "Más hermosa que el sol», Sab 7, 29, es propuesta por Aresi como

52 Gasch, C. 1730. El consuelo más piadoso en el sentimiento más justo. Oración Fúnebre en las solemnes exequias a la inmortal memoria del Ilustrísimo y Reverendísimo Señor Fr. Don Joseph Gasch, ex-General de toda la Religión Mínima. En Valencia: por Vicente Cabrera.

53 Arbiol, A. 1736. Estragos de la luxuria y sus remedios, conforme a las Divinas Escrituras, y Santos Padres de la Iglesia: 26. En Barcelona: por Pablo Campins.

54 Soto y Marne, F. 1738. Florilogio Sacro, que en el celestial ameno frondoso Parnasso de la Iglesia, riega (Mysticas flores) la Aganipe Sagrada Fuente de Gracia, y Gloria, Cristo: 239 y 244. Salamanca: en la Imprenta de la Sta. Cruz, por Antonio Villarroel y Torres. 
ejemplo del enamorado profano). ${ }^{55}$ La de las serpientes que huyen de la sombra de las ramas del fresno, es reflejo de la necesidad de apartarse de la ocasión para vencer la lujuria (empresa 85 de la segunda parte del libro cuarto, Fugae praesidium sumunt, "Toman por remedio la fuga», Jdt 15, 1, dedicada al obispo san Hilario)..$^{56}$ Y la empresa del pez volador -que el orador español confunde con una golondrinaes imagen del hombre contemplativo (empresa 12 del libro segundo, que lleva por lema Sursum et subter, «En lo alto y en lo bajo", $D t 33,27$, y le sirve a Aresi para ejemplificar al santo a la vez contemplativo y activo)..$^{57}$

En fin, el P. Gaspar de Oliden, con cuya cita a Aresi abríamos este trabajo, nos servirá igualmente para cerrarlo. En su disertación acerca de las razones para que los fieles socorran a las almas del purgatorio, mostrando la aplicación y utilidad de las obras satisfactorias, se sirve de la empresa 151 del libro quinto de las Imprese sacre, que lleva por mote Ut ascendam («Para que suba» $\mathrm{Hab} 3,16$ ). Su pictura muestra un cohete encendido que asciende al cielo (Fig. 20), imagen que el obispo teatino emplea igualmente para ejemplificar el beneficio que proporcionan nuestras buenas acciones a las almas del purgatorio. ${ }^{58}$

\section{FIGURA 20}

\section{Imprese sacre, Libro V, empresa 151: Ut ascendam}

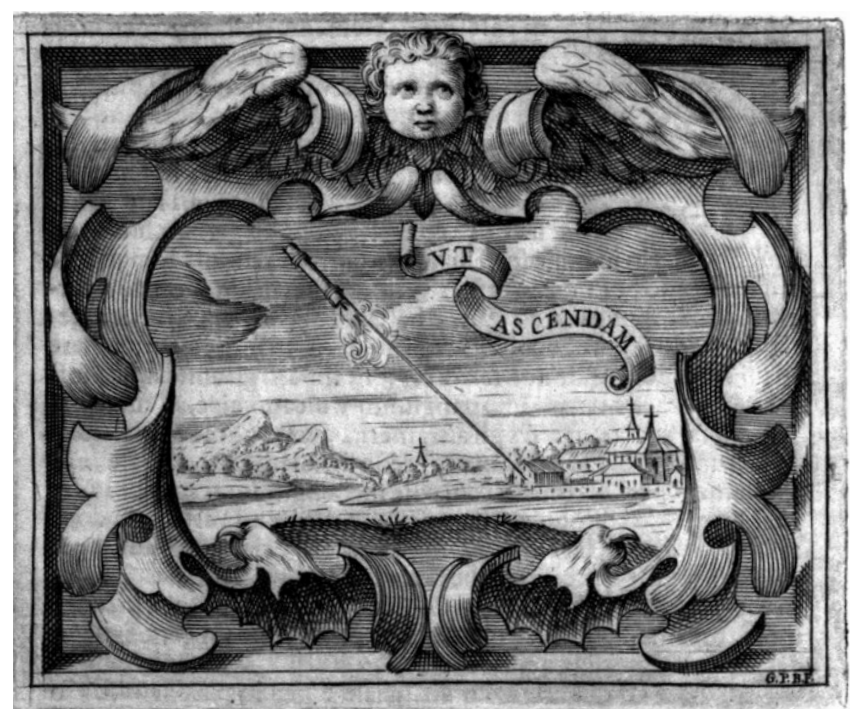

\section{CONCLUSIÓN}

La composición de las Imprese sacre de Paolo Aresi, una de las más importantes colecciones de imágenes simbólicas para uso de los predicadores de toda la producción del siglo XVII, responde a la preocupación de utilizar en el discurso

55 Suárez de Figueroa, D. 1732. P. Ovidio Nasón. De el remedio de el amor impuro. Le comenta, e ilustra el Doctor Don Diego Suarez de Figueroa. Tomo Tercero: 66-67. Madrid.

56 Suárez de Figueroa, D. 1727a. Vida, excelencias, y muerte del Gloriosissimo Patriarca San Joseph. Escribiola el Maestro Don Joseph de Valdivieso, Mozarabe en la Santa Iglesia de Toledo. Comentala el Doctor Don Diego Suarez de Figueroa. Tomo Primero: 440. Madrid: en la Oficina de Francisco del Hierro.

57 Ibídem: 237.

58 Oliden, G. 1732: 44. homilético los instrumentos de persuasión más eficaces. El binomio predicación-imagen se muestra efectivo en su idea de "predicar a los ojos» que, como analiza G. Ledda, promueve la presencia de la ausencia. El compendio emblemático de Aresi traspasó muy pronto el ámbito italiano para llegar a España, donde los oradores sagrados se sirvieron de las empresas del teatino como recurso visual en sus homilías. Sin duda, el hecho de que hubieran sido compuestas por un religioso que, además de obtener gran fama como predicador, alcanzó la dignidad de obispo de Tortona, confería autoridad y despejaba cualquier duda acerca de su idoneidad y aprovechamiento en la oratoria sagrada. Al cumplirse el IV Centenario de la publicación del primer libro de las Imprese sacre, ha sido nuestro propósito demostrar la presencia e influencia del «erudito Aresio» en el ámbito hispano.

\section{BiBLIOGRAFÍA}

Andreu, F. 1962. "Arese (Aresi), Paolo», en Dizionario biografico degli italiani, Vol. 4: 84-85. Roma: Istituto della Enciclopedia Italiana.

Aranaz, J. 1713. Quaresma continua. Primera parte de Sermones en las Ferias Mayores. Pamplona: Real Convento de Nuestra Señora del Carmen.

Arbiol, A. 1736. Estragos de la luxuria y sus remedios, conforme a las Divinas Escrituras, y Santos Padres de la Iglesia. En Barcelona: por Pablo Campins.

Ardissino, E. 1998. «Immagini per la predicazione: le imprese sacre di Paolo Aresi». Rivista di Storia e Letteratura Religiosa XXXIV: 3-25.

Ardissino, E. 2001. II Barocco e II Sacro. La predicazione del teatino Paolo Aresi tra letteratura, immagini et scienza. Città del Vaticano: Libreria Editrice Vaticana.

Aresi, P. 1615. Delle imprese sacre. Libro primo. Verona: Apresso Angelo Tamo.

Aresi. P. 1621. Imprese sacre. Libri primo-terzo. Milano: Herede di P. Pontio e G. B. Piccaglia per li Impressori Archiepiscopali.

Aresi, P. 1630a. Delle sacre imprese. Libro quarto. Tortona: per Pietro Giovanni Calenzano et Eliseo Viola Compagni.

Aresi, P. 1630b. Delle sacre imprese. Libro quarto, Volume Secondo. Tortona: per Pietro Giovanni Calenzano et Eliseo Viola Compagni.

Aresi, P. 1630c. Delle sacre imprese. Libro quinto. Tortona: per Pietro Giovanni Calenzano et Eliseo Viola Compagni.

Aresi, P. 1634. Delle sacre imprese. Libro sesto. Parte prima. Tortona: per Pietro Giovanni Calenzano et Eliseo Viola Compagni.

Aresi, P. 1635. Delle sacre imprese. Libro sesto. Parte seconda. Tortona: per Pietro Giovanni Calenzano.

Aresi, P. 1640. La retroguardia. Libro settimo delle sacre imprese. Genova: Per Giovanni Calenzani.

Azanza López, J. J. 2010. «Alciato moralizado. Los emblemas alciatinos como exempla en la oratoria sagrada», en I. Arellano y A. Martínez Pereira (eds.), Emblemática y religión en la Península Ibérica (Siglo de Oro): 71-100. Madrid \& Frankfurt: Iberoamericana \& Vervuert.

Azanza López, J. J. 2012. «Emblemática italiana y festividad hispana: las Imprese sacre del obispo Aresi en las grandes solemnidades de la Virgen y los santos», en R. Camacho, E. Asenjo y B. Calderón (coords. y eds.), Fiestas y mecenazgo en las relaciones culturales del Mediterráneo en la Edad Moderna: 137-162. Málaga: Ministerio de Economía y Competitividad y Universidad de Málaga.

Azanza López, J. J. 2013. «Imágenes emblemáticas para el adoctrinamiento regio: los sermones del predicador real José Barcia en la Corte de Carlos II». Potestas. Revista del Grupo Europeo de Investigación Histórica 6: 255-297.

Azanza López, J. J. 2015. «Empresas y emblemas en un manuscrito de la Biblioteca Histórica de Santa Cruz (Valladolid)». BSAA arte LXXXI: 137-161.

Barcia y Zambrana, J. 1692. Despertador Christiano, Marial, de varios sermones de María Santissima Nuestra Señora en sus festividades. En Madrid: Por Juan García Infanzon.

Barcia y Zambrana, J. 1694. Despertador Christiano Santoral, de varios Sermones de Santos, de Anniversarios de Animas, y Honras, en 
orden a excitar en los fieles la devoción de los Santos, y la imitación de sus virtudes. Cádiz: en casa de Christobal de Requena, Impressor de Su llustrissima.

Barcia y Zambrana, J. 1697. Despertador Christiano Cuadragesimal de Sermones doctrinales para todos los dias de la Quaresma. Tomo Segundo. Madrid: por Antonio Román.

Barón, J. 1732. Remedio Universal de todas las necessidades y trabajos, el Rosario de María SSma., Madre de Dios, y de pecadores. Tomo Primero. En Zaragoza: En la Imprenta Real de Luis de Cueto.

Barón, J. 1790. Luz de la Senda de la virtud, Desiderio y electo en e camino de la perfección. Tercera parte del Segundo Tomo. Madrid: en la Imprenta de Don Benito Cano.

Bernat Vistarini, A. y Cull, J. T. 2010. «Pues si miramos en este escudo imperial: imbricación de palabra e imagen en el sermón de Jerónimo de Florencia (S. J.) para las exequias funerales en honor de la emperatriz María de Austria», en I. Arellano y A. Martínez Pereira (eds.), Emblemática y religión en la Península Ibérica (Siglo de Oro): 101-127. Madrid \& Frankfurt: Iberoamericana \& Vervuert.

Borroni, F. 1968. «Bianchi, Giovanni Paolo», en Dizionario biografico degli italiani, Vol. 10: 122-123. Roma: Istituto della Enciclopedia Italiana.

Cerdán, F. 1993. "La emergencia del estilo culto en la oratoria sagrada del siglo XVII». Criticón 58: 61-72.

Cicala, G. 1644. Oratione detta in S. Antonio di Milano a dí 20 di giugno 1644 nelle esequie di monsignor Paolo Aresi, vescovo di Tortona, teatino. Milano: Roda in Porta Romana.

Cull, J. T. 2004. "The Baroque at Play: Homiletic and Pedagogical Emblems in Francisco Garau and Other Spanish Golden Age Preachers», en F. A. de Armas (ed.), Writing for the Eyes in the Spanish Golden Age: 237-256. Lewisburg: Bucknell University Press.

Díaz de Bustamante, J. M. 1996. "Sobre los orígenes del emblema literario: lemmata y contexto», en S. López Poza (ed.), Literatura emblemática hispana. Actas del I Simposio Internacional: 61-73. A Coruña, Universidade da Coruña.

Egido Martínez, A. 1992. "Emblemática y literatura», en A. Egido (coord.), Historia y crítica de la literatura española, Vol. 3, Tomo 2. Siglo de Oro. Barroco: primer Suplemento: 81-85. Barcelona: Editorial Crítica.

Esquirol y Murillo, J. 1727. Didascalia Evangélica y Cuadragesimal, para todas las ferias, mayores, y menores, de la Cuaresma. Zaragoza: en la Imprenta de Pedro Ximénez.

Fernández Navarrete, D. 1676. Tratados históricos, politicos-ethicos, y religiosos de la monarchia de China. En Madrid: En la Imprenta Real.

García Arranz, J. J. 1996. «Paradisea avis: la imagen de la naturaleza exótica al servicio de la enseñanza didáctico-religiosa en la Edad Moderna». Norba Arte XVI: 131-152.

García Arranz, J. J. 2010. Symbola et emblemata avium. Las aves en los libros de emblemas y empresas de los siglos XVI y XVII. A Coruña: SIELAE y Sociedad de Cultura Valle Inclán.

Gasch, C. 1730. El consuelo más piadoso en el sentimiento más justo. Oración Fúnebre en las solemnes exequias a la inmortal memoria del Ilustrísimo y Reverendísimo Señor Fr. Don Joseph Gasch, ex-General de toda la Religión Mínima. En Valencia: por Vicente Cabrera.

Gómez Bravo, E. 1997. «Picinelli en español», en El Mundo Simbólico. Libro I. Los cuerpos celestes: 9-28. Zamora (México): El Colegio de Michoacán.

González de Mendoza, J. 1586. Historia de las cosas más notables, ritos y costumbres del gran Reyno de la China. Madrid: en casa de Pedro Madrigal.

Gracia, D. 1711. Sermones de Christo, su Santissima Madre, y algunos de los primeros Santos de la Iglesia. Zaragoza: por Manuel Román, Impressor de la Universidad, y de la Santa Iglesia Metropolitana.

Herrera Dávila, J. y Alvear, A. 1829. Lecciones de historia del imperio chino. Breve descripción de este Imperio, de su historia, población, gobierno, religión, industria, usos y costumbres. Sevilla: Imprenta de H. Dávila, Lleba y Compañía.

Ledda, G. 1989. «Predicar a los ojos». Edad de Oro 8: 129-142.

Ledda, G. 1996. "Los jeroglíficos en los sermones barrocos. Desde la palabra a la imagen, desde la imagen a la palabra», en S. López Poza (ed.), Literatura emblemática hispánica: actas del I Simposio Internacional: 111-118. La Coruña: Universidade da Coruña.

Ledda, G. 1998. «Emblemas y configuraciones emblemáticas en la literatura religiosa y moral del siglo XVII», en M. C. García de Enterría y A. Cordón Mesa (eds.), Actas del IV Congreso Internacional de la Asociación Internacional Siglo de Oro, Vol. 1: 45-74. Alcalá de Henares: Universidad de Alcalá.

Ledda, G. 2003. La parola e l' immagine. Strategie della persuasione religiosa nella Spagna secentesca. Pisa: Edizioni ETS.

López Poza, S. 2000. "Los libros de emblemas como tesoros de erudición auxiliares de la inventio», en R. Zafra y J. J. Azanza (eds.), Emblemata Aurea. La Emblemática en el Arte y la Literatura del Siglo de Oro: 263-279. Madrid: Akal.

Murcia, J. B. 1755. Sermones para todos los domingos del año, y para las ferias mayores de la Quaresma, y asuntos de la Semana Santa. Divídese en dos tomos. Tomo Primero. Barcelona: en la Imprenta de Carlos Sapèra, y Jayme Ofset Libreros.

Niseno, D. 1638. Segunda parte del Político del Cielo. Hallado en las Misteriosas acciones del sagrado patriarca Jacob. Barcelona: a costa de Sebastián de Comellas Mercader.

Niseno, D. 1650. El lucero de la tarde S. Juan, Apostol, Evangelista, y Profeta, en asuntos predicables, morales, esornatorios. Madrid: en la Imprenta de María de Quiñones.

Oliden, G. 1732. Diálogos del purgatorio, para examen de un libro. Alcalá y Madrid en la Librería de Juan de Buytrago.

Pérez Martínez, H. 2000. «El emblematismo argumentativo en un sermón novohispano. El panegírico de Palavicino sobre La fineza mayor», en V. Mínguez (ed.), Del Libro de Emblemas a la Ciudad Simbólica, Vol. II: 603-620. Castellón: Universitat Jaume I.

Piccinelli, F. 1653. Mondo simbolico o sia Università d'imprese suelte, spiegate, ed illustrate con sentenze, ed eruditioni sacre, et profane. In Milano: Per lo Stampatore Archiepiscopale.

Praz, M. 1989. Imágenes del Barroco (estudios de emblemática). Madrid: Ediciones Siruela.

Soto y Marne, F. 1738. Florilogio Sacro, que en el celestial ameno frondoso Parnasso de la Iglesia, riega (Mysticas flores) la Aganipe Sagrada Fuente de Gracia, y Gloria, Cristo. Salamanca: en la Imprenta de la Sta. Cruz, por Antonio Villarroel y Torres.

Suárez de Figueroa, D. 1727a. Vida, excelencias, y muerte del Gloriosissimo Patriarca San Joseph. Escribiola el Maestro Don Joseph de Valdivieso, Mozarabe en la Santa Iglesia e Toledo. Comentala el Doctor Don Diego Suarez de Figueroa. Tomo Primero. Madrid: en la Oficina de Francisco del Hierro.

Suárez de Figueroa, D. 1727b. Vida, excelencias, y muerte del Gloriosissimo Patriarca San Joseph. Escribiola el Maestro Don Joseph de Valdivieso, Mozarabe en la Santa Iglesia e Toledo. Comentala el Doctor Don Diego Suarez de Figueroa. Tomo Segundo. Madrid: en la Oficina de Francisco del Hierro.

Suárez de Figueroa, D. 1728a. Vida, excelencias, y muerte del Gloriosissimo Patriarca San Joseph. Escribiola el Maestro Don Joseph de Valdivieso, Mozarabe en la Santa Iglesia e Toledo. Comentala el Doctor Don Diego Suarez de Figueroa. Tomo Tercero. Madrid.

Suárez de Figueroa, D. 1728b. Vida, excelencias, y muerte del Gloriosissimo Patriarca San Joseph. Escribiola el Maestro Don Joseph de Valdivieso, Mozarabe en la Santa Iglesia e Toledo. Comentala el Doctor Don Diego Suarez de Figueroa. Tomo Cuarto. Madrid.

Suárez de Figueroa, D. 1728c. Vida, excelencias, y muerte del Gloriosissimo Patriarca San Joseph. Escribiola el Maestro Don Joseph de Valdivieso, Mozarabe en la Santa Iglesia e Toledo. Comentala el Doctor Don Diego Suarez de Figueroa. Tomo Quinto. Madrid.

Suárez de Figueroa, D. 1732. P. Ovidio Nasón. De el remedio de el amor impuro. Le comenta, e ilustra el Doctor Don Diego Suarez de Figueroa. Tomo Tercero. Madrid.

Suárez de Figueroa, D. 1738. Camino de el Cielo. Emblemas Cristianas. A devoción y de orden de la Sesenissima Señora Doña Maria Francisca Xavier Barbara, Princessa de Asturias. Madrid.

Tanganelli, P. 2002. «Descripción jeroglífica y retórica de la empresa: Pedro de Valderrama y Sambuco», en A. Bernat y J. T. Cull (eds.), Los días del Alción. Emblemas, Literatura y Arte del Siglo de Oro: 533-545. Barcelona: J. J. de Olañeta.

Terrones del Caño, F. 2001. Obras Completas. Valladolid: Junta de Castilla y León. Universidad de León.

Valeriano, P. 1556. Hieroglyphica, siue de sacris Aegyptiorum literis commentarii. Basileae: Michael Isengrin.

Vegecio Renato, F. 2006. Compendio de técnica militar (ed. David Paniagua Aguilar). Madrid: Cátedra. 